\title{
VIDA-forskningsrapport 4
}
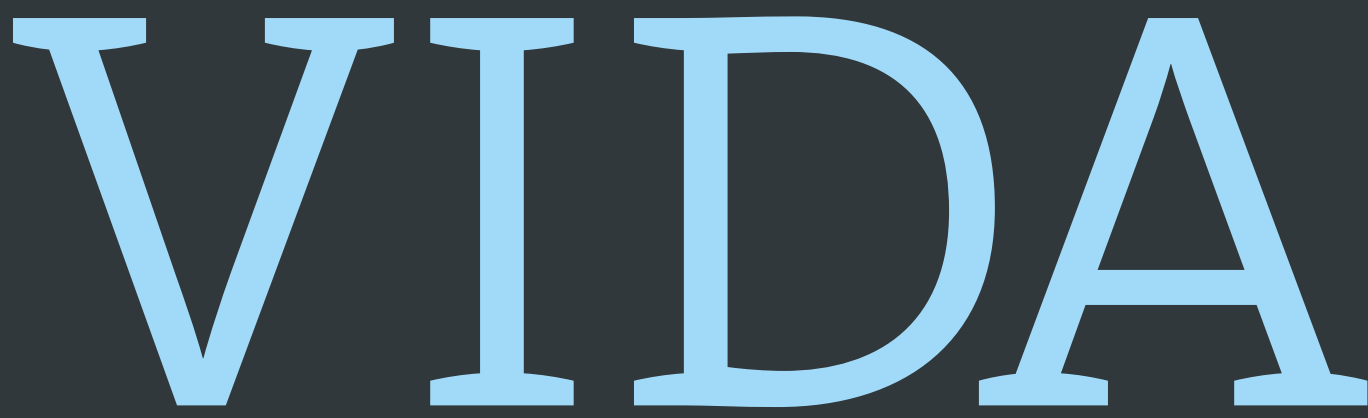

Vidensbaseret indsats over for udsatte børn i dagtilbud - modelprogram Forandring og effekt

Bente Jensen 
VIDA-forskningsserien 2013:07

VIDA-FORSKNINGSRAPPORT 4

\section{VIDENSBASERET INDSATS OVER FOR UDSATTE BØRN I DAGTILBUD}

- MODELPROGRAM

FORANDRING OG EFFEKT

BENTE JENSEN 


\title{
Vidensbaseret indsats over for udsatte børn i dagtilbud - Modelprogram \\ Forandring og effekt \\ VIDA-forskningsrapport 4 \\ VIDA-forskningsserien 2013:07
}

\author{
ISSN 1904-8521 (Web-udgave) \\ ISSN: $1904-8947$ (Print-udgave) \\ ISBN: 978-87-7507-344-3 (Web-udgave) \\ DOI: $10.7146 /$ aul.73.67
}

\section{(C) 2013 by VIDA-projektet}

\section{VIDA-projektets ekspertgruppe}

Professor Dorthe Bleses, Center for børnesprog, Syddansk Universitet

Professor Kenneth Mølbjerg Jørgensen, Institut for Læring og Filosofi (SAMF), Aalborg Universitet

Professor Mads Meier Jæger, Aarhus Universitet, Institut for Uddannelse og Pædagogik

Seniorforsker Mogens Christoffersen, SFI - Det Nationale Forskningscenter for Velfærd

Docent Sven Bremberg, Institutionen för folkhälsovetenskap, Karolinska Institutet

Professor emeritus Svend Erik Nordenbo, Aarhus Universitet

Denne rapport er en sammenfatning af undersøgelser gennemført i tilknytning til forskningsprogrammet VIDA, Vidensbaseret indsats over for udsatte børn i dagtilbud. VIDA blev gennemført 2010-2013 og afsluttet med en række publikationer, status- og modelrapporter samt forskningsrapporter.

Oplysninger om forskningsprogrammet kan findes på http://edu.au.dk/forskning/projekter/vida/.

\section{Forfatter}

Bente Jensen

Denne rapport citeres som: Jensen, B., (2013) Vidensbaseret indsats over for udsatte børn i dagtilbud - modelprogram. VIDA-forskningsrapport 4. Forandring og effekt I: VIDA-forskningsserien 2013:07. Aarhus Universitet, IUP

Udgivet: December 2013

Grafisk design: Leif Glud Holm

Tryk: Rosendahls - Schultz Grafisk

Aarhus Universitet, Institut for Uddannelse og Pædagogik,

Tuborgvej 164

2400 København NV

Telefon: 87161300

http://edu.au.dk/forskning/projekter/vida/

Bente Jensen - bj@dpu.dk

VIDA's publikationer kan frit citeres med tydelig angivelse af kilden.

Skrifter, der omtaler, anmelder, henviser til eller gengiver VIDA's publikationer, bedes sendt til VIDA-projektet, Aarhus Universitet, Institut for Uddannelse og Pædagogik. 


\section{INDHOLD}

FORORD

RESUMÉ

1 FORSKNINGSPROGRAMMETS FORMÅL OG PERSPEKTIVER 15

1.1 BAGGRUND OG FORMÅL 15

$\begin{array}{lll}1.2 & \text { ET SAMLET VIDA- KONCEPT } & 21\end{array}$

1.3 VIDA-PROGRAMMET 24

2 VIDA PROGRAMMETS EFFEKTER - OVERORDNEDE TRAKK 35

$2.1 \quad$ DESIGN OG DATA 35

$\begin{array}{lll}\text { 2.2. OVERORDNEDE FUND } & 37\end{array}$

$\begin{array}{lll}2.3 & \text { SAMMENFATNING } & 41\end{array}$

3 KONKRETE FORANDRINGER I PRAKSIS SOM FøLGE AF VIDA - CASESTUDIER 43

3.1 ANALYSE AF FORANDRINGER BASERET PÅ CASESTUDIER AF ORGANISATORISK LÆERING 43

3.2 KONKRETE INDSATSER RETTET IMOD NYE FORMER FOR FORÆLDREINDDRAGELSE 49

3.3 SAMMENFATNING 54

$4 \quad$ REFLEKSION OVER FORSKNINGSPROGRAMMETS RESULTATER

4.1 SOCIAL ARV SOM SOCIAL OG KULTUREL ULIGHED -

HVORDAN GØR VIDA EN FORSKEL? $\quad 58$

4.2 FORUDS/ETNINGER FOR FORANDRINGER $\quad 59$

4.3 EFFEKTER OVER TID, VILKÅR OG RESSOURCER 61

$\begin{array}{ll}\text { AFSLUTNING } & 63\end{array}$

$\begin{array}{lr}\text { REFERENCER } & 65\end{array}$ 



\section{FORORD}

Forskningsprogrammet VIDA - vidensbaseret indsats over for udsatte børn i dagtilbud - modelprogram, har haft som formål at unders $\varnothing$ ge virkninger af at sætte en målrettet, systematisk og vidensbaseret indsats ind i danske dagtilbud for at se, om dette kunne være et bidrag i indsatsen imod social arv og ulighed i vort samfund. I denne rapport sammenfattes resultaterne fra unders $\varnothing$ gelsen af effekter målt på børns udbytte af VIDA-modelprogrammerne i danske daginstitutioner fra 2011 til 2013. Desuden sammenfattes resultaterne af de to casestudier, der er gennemf $\varnothing$ rt sidel $\varnothing$ bende med effektstudiet. Formålet med VIDA er at styrke børns udbytte af en $\varnothing$ get kvalitetsindsats i dagtilbud. Mere specifikt er vi interesserede $i$, om denne form for intervention $i$ daginstitutioner når alle børn og således også mere specifikt socialt udsatte børn.

Programmets design, metoder, gennemf $\varnothing$ relse mv. er beskrevet i VIDA-forskningsseriens rapporter fra 2011-2013. En oversigt over VIDA-programmets samlede 'værktøjskasse' kan desuden findes på projektets hjemmeside http://edu. au.dk/forskning/projekter/vida/.

I denne VIDA-forskningsrapport 4. Forandringsprocesser og effekt i dagtilbud - baseret på de samlede resultater af effekt- og casestudier i VIDA - opsummeres resultater af analysen af effekter af VIDA-modelprogrammerne. Rapporten præsenterer indledningsvis VIDA-programmets form, baggrund og konkrete interventioner, VIDA-Basis og VIDA-Basis + (kap.1). Efterfølgende præsenteres VIDA-programmets overordnede effekter målt på børns udbytte gennem et randomiseret, kontrolleret eksperimentdesign (RCT) (kap. 2). Derefter opsummeres 
resultater fra de to casestudier, der er gennemført med henblik på at unders $\varnothing$ ge, om og hvordan forandringsprocesser i pædagogiske uddannelsesinstitutioner har fundet sted - både med henblik på organisatorisk læring og med henblik på forældresamarbejde på nye måder (kap. 3). Endelig sammenfattes rapporten i refleksioner over forskningsprogrammets samlede resultater (kap. 4). Afslutningsvis fremsættes en konklusion og perspektiver for, hvordan viden og erfaringer fra VIDA-projektet kan implementeres fremover.

Rapporten er udarbejdet af professor, ph.d. Bente Jensen, Aarhus Universitet, der også har haft ansvaret for ledelse af det samlede forskningsprogram. Rapporten er diskuteret og kommenteret med forfatterne, der har været involveret i undersøgelserne, der ligger bag.

Projektets styregruppe ved Helle Beknes, Social-, Børne- og Integrationsministeriet, samt ekspertgtuppen knyttet til VIDA-projektet ved Sven Erik Nordenbo har bidraget med nyttige kritiske og konstruktive kommentarer til VIDA-forskningsrapport 4.. Konsulent og cand.mag. i retorik, projektmedarbejder Jakob Haahr-Pedersen og Kirsten Kovacs takkes for hhv. bearbejdning, råd og korrekturlæsning på manuskriptet. Endelig takkes Leif Glud Holm for grafisk design og opsætning.

VIDA-modelprogrammet er finansieret af Social-, Børne- og Integrationsministeriet.

København, november 2013

\section{Bente Jensen}

Professor, ph.d., projektleder, Aarhus Universitet, Institut for Uddannelse og Pædagogik 


\section{RESUMÉ}

I denne VIDA-forskningsrapport 4, "Vidensbaseret indsats over for udsatte børn $i$ dagtilbud - modelprogram. Effekter af VIDA", præsenteres en samlet oversigt over VIDA-projektets forskningsmæssige formål og baggrund, VIDA-interventionens curriculum samt strategier for professionel kvalificering (kap. 1). Derefter beskrives data, design og analysestrategier og resultater af effektunders $\varnothing$ gelsen målt på børns udbytte (kap. 2). Efterfølgende præsenteres casestudierne, som belyser forandringsprocesser i dagtilbud som følge af deltagelse i VIDA-programmet både med hensyn til organisatorisk læring og med hensyn til nye former for forældresamarbejde (kap. 3). Endelig samles resultaterne i rapporten i en refleksion over resultater fra de tre delstudier (kap. 4). Rapporten afsluttes med en opsummering og perspektivering.

\section{VIDA - EN INNOVATIV TILGANG TIL TIDLIG INDSATS}

VIDA-programmet, som er gennemført (2010-2013) og nu evalueret (2013), adskiller sig fra den internationale forskning i effekter af en tidlig indsats i dagtilbud på tre måder. For det første ved at indsatsen skal implementeres i universelle dagtilbud, hvor $97 \%$ af alle danske 3-5-årige børn deltager (jf. Danmarks Statistik, 2010). I de internationale programmer, som VIDA i $\varnothing$ vrigt er inspireret af, er indsatsen typisk målrettet en udvalgt gruppe og mere specifikt et udvalg af udsatte $\mathrm{b} \phi \mathrm{rn}$. Disse indsatser gennemføres i små grupper af børn, og indsatsen finder sted i udvalgte lokalområder, oftest i USA. For det andet ved at indsatsen skal fremme $b \varnothing$ rns trivsel og læring i bredt perspektiv, som angivet i det danske nationale curriculum (Bekendtgørelse om Pædagogiske Læreplaner, Socialministeriet, 
2004), og således ikke bygge på en bestemt metode og manual. I internationale programmer retter indsatsen sig oftest imod at stimulere børn på et specifikt kompetenceområde, fx sprog, og så arbejdes der målrettet med dette område i en nærmere afgrænset periode. For det tredje ved at indsatsen skal gennemf $\varnothing$ res af professionelle, som i forvejen arbejder i dagtilbuddet - dvs. ikke af specialister, men af en blanding af pædagoger med en professionsbachelorgrad og ikkeuddannede medarbejdere - og i en pædagogisk kontekst med tradition for autonomi og metodefrihed. I internationale programmer er de professionelle, der gennemf $\varnothing$ rer indsatsen, ofte specialister på netop det område, som indsatsen drejer sig om, og de modtager desuden instruktion i at anvende specifikke metoder og manualer.

\section{INTEGRERET EFFEKTFORSKNING}

I alt blev der udtrukket 129 daginstitutioner (89 interventionsinstitutioner og 40 kontrolinstitutioner) fra fire kommuner til et randomiseret, kontrolleret fors $\varnothing \mathrm{g}$ (lodtrækningsfors $\varnothing$ g). Der blev i tre omgange udsendt spørgeskemaer, som blev udfyldt af pædagogerne for hvert barn: ved starten af interventionen (1. runde), midtvejs (2. runde) og afslutningsvis (3. runde). Effekterne analyseres på basis af målingsredskaber, som er internationalt anerkendte, og som måler børns socioemotionelle kompetencer og læringskompetencer og med pædagoger som informanter. De samme målingsredskaber er tidligere anvendt og afprøvet i HPA-projektet (2005-2009), som går forud for VIDA-projektet ${ }^{1}$.

Disse effektforskningsmetoder g $\varnothing \mathrm{r}$ det for det første muligt at belyse, om børn i VIDA-interventionsinstitutioner klarer sig bedre med hensyn til udvikling af sociale kompetencer og læringskompetencer end børn i kontrolinstitutionerne. For det andet bliver det muligt at unders $\emptyset$ ge faktorer af betydning for effekterne, bl.a. kommuners organisering, ressourceforbrug og evt. andre satsninger, lederog pædagogstabilitet vs. udskiftning, børnesammensætning mv. Sådanne faktorer samt indikatorer på forskelle på implementeringsprocesser i hhv. et organisatorisk læringsperspektiv og et forældreinddragelsesperspektiv, som vi kunne identificere ved at se nærmere på data fra casestudierne, vil kunne inddrages i analyserne ved en senere lejlighed for at se på sammenhænge med effekt. Endelig for det tredje giver den analytiske tilgang, der kombinerer kvantitative og kvalitative data, mulighed for at udvikle ny viden om sammenhænge mellem implementering og effekt. Kun resultater af den kvantitative del af effektstudiet præsenteres i nærværende rapport.

1 Udover kvantitative målingsmetoder og analyser er der gennemført to casestudier, der er baseret på kvalitative interview og observationsstudier med fokus på hhv. organisatorisk læring og forældreinddragelse. 


\section{EFFEKTER AF VIDA MÅLT PÅ B $\varnothing$ RNS UDBYTTE}

I VIDA måler man, om indsatsen har virket, ved at pædagogerne udfylder et spørgeskema for hvert barn. Spфrgeskemaet rummer spørgsmål om barnets socioemotionelle udvikling fra Strengths and Difficulties Questionnaire (SDQ), der er internationalt anvendt og anerkendt. SDO måler fem dimensioner: Emotionelle problemer, adfærdsproblemer, hyperaktivitet, kammeratskabsproblemer og prosocial adfærd. Alle fem dimensioner behandles som separate udfald, og de fire første dimensioner kan summeres til en total score. Desuden giver SDQ også grundlag for beregning af et vanskelighedsindeks ('SDO impact score'). Kognitive kompetencer er målt på læringsmål inspireret af Qualifications and Curriculum Authority (OCA) med fokus på børns læring opdelt på områder relevante i forhold til pædagogiske læreplanstemaer, såsom sprog skriftligt og mundtligt, matematisk forståelse, naturforståelse etc.

Der er sket en måling af børnene i tre runder. Antallet af børn, der har deltaget i hver af de tre dataindsamlingsrunder, er vist i tabellen nedenfor. Det fremgår, at ud af de knap 7.000 børn, som deltog i den første dataindsamlingsrunde, er der $2.160 \mathrm{~b} \varnothing \mathrm{rn}$, som deltager i alle tre runder.

Tabel: Antal børn i hver dataindsamlingsrunde, samt antal børn, som også deltog i forrige dataindsamlingsrunde.

\begin{tabular}{|c|c|c|}
\hline Runde & $\begin{array}{c}\text { Totalt antal børn i } \\
\text { runden }\end{array}$ & $\begin{array}{c}\text { Heraf antal børn } \\
\text { fra alle forrige runder }\end{array}$ \\
\hline 1 & 6.833 & - \\
\hline 2 & 7.472 & 4.602 \\
\hline 3 & 6.911 & 2.160 \\
\hline
\end{tabular}

\section{Effekter på børn}

Det overordnede billede er, at VIDA-interventionen har haft positive effekter på flere SDQ-dimensioner. Resultaterne viser for det første, at VIDA-Basis-interventionen signifikant forbedrer to af de fem SDQ-dimensioner: Børns emotionelle problemer og adfærdsproblemer reduceres. De tre $\varnothing$ vrige dimensioner er også forbedret, idet hyperaktivitet og kammeratskabsproblemer er reduceret og prosocial adfærd fremmet. Disse effekter er dog ikke signifikante. 
Det skal endvidere understreges, at den totale SDO score (som repræsenterer summen af de første fire dimensioner) også er signifikant forbedret for VIDABasis-interventionen.

Resultaterne viser for det andet, at VIDA-Basis +-interventionen også har haft positive effekter. Det er dog kun en ud af de fem SDO-dimensioner, der er signifikant forbedret: Børns adfærdsproblemer er reduceret. Generelt er effekterne af VIDA-Basis +-interventionen mindre end de tilsvarende effekter af VIDA-Basis. Ud over de ovennævnte SDQ-dimensioner og den totale score er der benyttet et særskilt supplement, hvor pædagogerne har svaret på, om de samlet set vurderer, at barnet har vanskeligheder på de sociale og personlige områder, som indgår i SDO-spørgsmålene. På baggrund af disse svar er der beregnet et vanskelighedsindeks ('SDO impact score'). Analyser af effekten af VIDA-Basis- og VIDA-Basis +-interventionerne på dette vanskelighedsindeks bekræfter de overordnede positive effekter.

Sammenfattende viser analysen VIDA har en effekt på alle børn - ift. trivsel og socio-emotionel udvikling, (ikke kognitive), men det er ikke sådan, at programmet i særlig grad løfter de udsatte børn.

Der er dog enkelte undtagelser til dette generelle billede: VIDA-Basis har været i stand til signifikant at formindske kammeratskabsproblemer for børn af anden etnisk baggrund end dansk. Derudover er der en særskilt positiv effekt af VIDABasis+ for børn fra lavindkomstfamilier, idet kammeratskabsproblemer for disse børn er mindsket signifikant gennem indsatsen.

\section{Forskelle}

Når vi unders $\emptyset$ ger forskelle i effekterne mellem institutioner med en høj andel af socialt udsatte børn ( $\geq 40 \%$ ) og institutioner med en lavere andel, så er hovedresultatet igen, at der ikke findes signifikante forskelle, dog med undtagelse af emotionelle problemer. Vi finder således, at VIDA-Basis ikke medf $\varnothing$ rer nogen signifikant forbedring for børn i institutioner med mange udsatte børn, mens VIDA-Basis + giver en signifikant forbedring for børn i institutioner med mange udsatte børn.

Billedet ændrer sig noget, når vi ser på den anden del af det samlede kompetencemønster hos børnene, nemlig de intellektuelle områder og børns læring. Her viser det sig nemlig, at der ikke kan påvises effekter af VIDA, hvad angår børns læringskompetencer og kognitive kapacitet på de unders $\varnothing$ gte indeks. Dette fund er overraskende sammenlignet med HPA-projektet. Her fandt vi nemlig, at 
på en enkelt faktor, der knytter sig til den kognitive side af børns kompetencer 'matematisk formåen', var der positiv effekt og det oven i købet en effekt, der slog signifikant igennem med bedre resultater for den svageste gruppe. Dette billede ser vi ikke i VIDA-analysen.

\section{Vilkår og implementeringsbetingelser}

Analysen antyder, at børnesammensætningen kan have betydning for effekten, fx at en sammensætning, som indebærer, at en stor andel af udsatte børn er indskrevet i samme institution, får konsekvenser for effekterne af en VIDA-intervention på børnenes emotionelle problemer. Selv om det er indbygget i interventionen, at institutionerne skal arbejde med inkluderende pædagogisk praksis, kan dette måske vanskeligg øres i institutioner med mange socialt udsatte børn, som måske kan give indre spændinger i børnegruppen. Andre udfordringer, der kan være på færde i den sammenhæng, kan være, at institutionerne er præget af det pres, der lægges på institutionerne i form af, som vi har set det, at andre tiltag sættes i gang i kommunen samtidigt. Nogle institutioner oplever desuden, at de savner bedre normeringer og faglige og personlige kompetencer, som gør dem bedre i stand til at mestre opgaven.

Endelig kan evt. forskelle på kommuners indsatser og tildeling af ressourcer og prioriteringer i forhold til at indgå i et målrettet og systematisk forskningsprojekt være af betydning. Nogle kommuner har valgt at gå ind i VIDA med en høj grad af politisk prioritering, opbakning og nedsættelse af projekt- og styregrupper i relation til at deltage i VIDA. Andre kommuner har haft en anden tilgang. Nogle af de forskelle, der træder tydeligst frem, er forskelle på, om kommunen koncentrerer indsatsen om ét program, nemlig VIDA, i projektperioden, eller om der igangsættes flere parallelt kørende projekter. Sådanne vil kunne udgøre risici i forhold til indsats og effekter. Det falder uden for nærværende rapports analyser at gå mere ind i disse forhold.

Efterfølgende opsummeres forandringsprocesser, der er sket i dagtilbuddene som følge af deltagelse i VIDA og dette med henblik på at give et samlet billede af forandring i praksis med effekter på børns udbytte.

\section{CASESTUDIER OM FORANDRINGER SOM FØLGE AF VIDA}

Casestudierne om hhv. organisatorisk læring og nye former for forældreinddragelse bidrager til at komme tættere på en forståelse af forandringsprocesser, der reelt er sket i dagtilbud, der deltager i VIDA, og som er grundlaget for de opnåede effekter målt på børns udbytte. 


\section{Organisatorisk læring}

Første del af analysen af casestudier, der er præsenteret i rapporten, viser opsummerende, at der er fundet markante, store virkninger af VIDA i positiv retning på især tre punkter vedrørende organisatorisk læring:

- Mere fokus på at arbejde med viden og på det at arbejde vidensbaseret, målrettet og systematisk med udsatte børn gennem forandringer af arbejdspladskulturen

- Ændrede ledelsesformer, lederroller og organisatorisk læringskapacitet, herunder en $\varnothing$ get oplevelse blandt medarbejderne af at møde opmuntring, st $\varnothing$ tte og positiv respons på udvikling af nye idéer og handlemåder

- $\quad$ ggede forventninger til VIDA-programmets effekter på kort og langt sigt og $\emptyset$ get motivation for at arbejde med VIDA for tre ud af fire kommuner.

Når det er sagt, må vi også erkende, at det stadig er en udfordring at arbejde med fornyelse på baggrund af VIDA-programmet på følgende to områder: Ressourcesynet er stadig en udfordring. Dette at arbejde væk fra 'fejlfinding' og hen imod at se på ressourcer hos børn, forældre og personale er slået igennem i mange dagtilbud, men det er stadig en udfordring at få alle medarbejdere med, som lederne udtrykker det i interview. Så selv om lederne fremhæver, at der nu arbejdes mere teoribaseret som følge af VIDA-programmets perspektiver, så er medarbejdergruppen forskelligartet, og denne gruppes forskelligheder er det en væsentlig ledelsesopgave at arbejde med - især i relation til VIDA-programmets mål om at styrke alle børns både trivsel og læring og satse særligt på at inkludere socialt udsatte børn. Ledelsen af organisatorisk læring har udviklet sig på afgørende vis fra 2011 til 2013.

Der, hvor der stadig er udfordringer, er i forhold til medarbejdernes oplevelse af medinddragelse. Dette punkt så vi også i en tidligere analyse (midtvejsanalysen), og der er således stadig behov for at videreudvikle dagtilbuddenes indsatsser på lige netop dette aspekt, så lederen differentierer mellem medarbejdere, men samtidig sikrer sig, at alle medarbejderne reelt oplever at være inddraget i at udvikle viden og nye pædagogiske praksisser frem imod målet at styrke alle børns sociale og kognitive udvikling og læring.

\section{Forældreinddragelse}

Konklusionen på anden del af casestudieanalysen vedrørende fornyet forældresamarbejde som følge af deltagelse i VIDA-Basis +-forældreprogrammet er, at der er sket en række positive forandringer på dette område, som især drejer sig om 
dagtilbuddenes $\emptyset$ gede prioriteringer af at samarbejde med forældre på en mere involverende måde. Studiet påviser, at der gennemgående arbejdes med en mere udviklingsorienteret og innovativ tilgang til forældresamarbejde efter forl $\varnothing$ bet med VIDA end i udgangspunktet (baseline). I flere institutioner fremhæves det, at institutionens arbejde med forældreinddragelse har haft en betydning i forældregruppen, på den måde at forældrene er mere accepterende og inkluderende over for hinanden.

Der er endvidere flere eksempler på, at forældre kan bruge personalet som sparringspartnere i forhold til de vanskeligheder, de oplever i relation til deres barn.

De udfordringer, der stadig foreligger i forhold til fornyelsen af forældresamarbejdet som følge af VIDA-Basis +-programmet er:

- Bevægelsen fra et fejl-/mangelsyn til et ressourcesyn i forhold til børn og forældre er en stadig udfordring. Personalet er meget forskellige steder, og stuerne griber det meget forskelligt an.

- Der er behov for andre måder at arbejde sammen på i personalegruppen, da udvikling af forældreinddragelse også handler om at arbejde med egen faglighed og samarbejde. I den sammenhæng er det en udfordring med professionalitet/faglighed omkring det at skabe ligeværdig dialog og at kunne håndtere forskelle som ressourcer og se forældre som bidragende.

- Variation i kommunikation og formidling til forældre, overskridelse af barrierer i forhold til direkte kontakt samt fastholdelse af et ressource- og anerkendelsesperspektiv i forbindelse med rådgivning og vejledning.

\section{KONKLUSION}

VIDA har en effekt på alle børn - ift. trivsel og socio-emotionel udvikling, (ikke kognitive læring), men det er ikke sådan, at programmet i særlig grad løfter de udsatte børn.

- VIDA gør en positiv forskel, især hvad angår den organisatoriske læring i form af målrettet og systematisk arbejde med forandring af pædagogisk praksis. Gennem det to-årige projektforl $\varnothing b$ er dagtilbuddenes arbejde blevet klart mere vidensbaseret, målrettet og systematisk, og den pædagogiske indsats er blevet fornyet i langt de fleste VIDA-dagtilbud. Casestudiet viser at VIDA ligeledes en positiv forskel i forbindelse med nye former for forældresamarbejdet, som også tages godt imod af forældrene. 
- De igangsatte forandringsprocesser har givet positive effekter på flere områder af alle børns social-emotionelle udvikling og trivsel. Der er derudover en særskilt positiv effekt af VIDA-Basis for børn af anden etnisk baggrund, idet kammeratskabsproblemer for disses børns vedkommende er mindsket signifikant gennem indsatsen, en effekt der ikke kan konstateres blandt de etnisk danske børn.

- Der er derudover en særkilt positiv effekt af VIDA-Basis+ for børn fra lavindkomstfamilier, idet kammeratskabsproblemer for disse børn er mindsket signifikant gennem indsatsen.

- VIDA-Basis+-forældremodelprogram har også haft positiv effekt på en ud af de fem dimensioner på socio-emotionelle udvikling, der er unders $\varnothing$ gt, hvor forældreinvolvering har vist sig at have signifikant effekt i reducering af adfærdsproblemer hos involverede børn.

- $\quad$ Overraskende har der ikke vist sig de forventede effekter på børnenes kognitive læring, ligesom der heller ikke er fundet særlige effekter af modelprogrammerne, hvad angår de mest udsatte børn. 


\section{KAPITEL 1}

\section{FORSKNINGSPROGRAMMETS FORMÅL OG PERSPEKTIVER}

\subsection{BAGGRUND OG FORMÅL}

VIDA er et nyt, innovativt interventions- og forskningsprogram, der er implementeret i dagtilbud for 3-6-årige børn i fire danske kommuner (2010-2013).

Forskningsprogrammet tager udgangspunkt i en politisk målsætning om at opnå ny, forskningsbaseret viden om, hvad der kan skabe kvalitet i dagtilbud, så alle børns sociale kompetencer og læring styrkes. Dette skal ses som led i en samlet bestræbelse på at unders $\varnothing$ ge, om og hvad et samfund kan gøre for at bekæmpe negativ social arv. Sådanne bestræbelser har været i gang længe som led i velfærdsstatens opg $\varnothing$ r med materiel og $\varnothing$ konomisk fattigdom og senere satsninger på at unders $\varnothing$ ge sammenhænge mellem uddannelsessystemer, opvækstvilkår og livschancer. Som vist i forskningsprogrammet 'Social arv' (2005) ser den sociale arv og dens konsekvenser imidlertid ud til at være relativt stabile. Dette fund underst $\varnothing$ ttes af seneste analyser af sammenhænge mellem social baggrund og mennesker livsmuligheder i bredeste forstand, som blev præsenteret i en rapport af AE-rådet (2012).

Behovet er dermed blevet aktualiseret for at gå nye veje og satse på kvalitetsforbedringer i dagtilbud.Der er behov for at udvikle nye former for forebyggelse af social marginalisering og udsathed, og i den sammenhæng anses fornyelse (innovation) i dagtilbud for at være et centralt sted at starte samfundets indsatser $i$ kampen imod de udfordringer, der er på færde. 
Denne form for forandring og omstilling, som er afprøvet i et tidligere projekt, HPA (2005-2009), har vist positive effekter, men det nævnte studie har også vist, at der er en række udfordringer, som må overkommes.

Målet med VIDA-projektet var at udvikle og implementere en ny, innovativ indsats i danske dagtilbud, som skulle leve op til følgende kriterier: 1) indsatsen skulle være for alle børn, da 97 \% af alle danske 3-6-årige børn er i dagtilbud (jf. opgørelser fra Danmarks Statistik), 2) indsatsen skulle fremme børns trivsel og læring i bredt perspektiv som angivet i det nationale curriculum (Bekendtg $\varnothing$ relse om pædagogiske læreplaner, Socialministeriet, 2004), og 3) indsatsen skulle kunne implementeres af de professionelle, som arbejder i dagtilbuddet, dvs. af pædagoger med professionsbachelorgrad såvel som af ikke-uddannede medarbejdere.

I de senere år, er det blevet klart, at børns livschancer grundlægges fra den tidligste alder. Tidlige interventioner i dagtilbud kan fremme børns livschancer og også mulighederne for børn af socialt udsatte familier, fx fattige familier. Det er derfor meget vigtigt at udvikle højkvalitetsdagtilbud og tidlige interventionsprogrammer, der kan styrke mulighederne for det enkeltes barns udvikling, trivsel og læring fra tidligste alder. Desuden søges der i interventionerne efter muligheder for at stå op imod virkningerne af fattigdom, der som vist i utallige studier har stærke implikationer for skoleparathed, uddannelsesmuligheder og for senere arbejdsmarkedstilknytning.

Det er derfor nødvendigt at få фget viden om, hvordan vi skal designe dagtilbuds lærings- og udviklingsprogrammer, så de bedst muligt fremmer alle børns livschancer fra tidligste alder. Samtidig er det påvist, at barnets socioemotionelle kompetencer og udvikling er lige så vigtige som kognitive kompetencer i forhold til at forstå, hvad der skaber grundlaget for børns livschancer og videre udvikling. Dette dobbelte perspektiv, at sigte imod børns socioemotionelle udvikling og samtidig imod den kognitive udvikling, er derved centralt at indarbejde og unders $\varnothing$ ge i nye interventioner.

I denne VIDA-forskningsrapport sammenfattes resultaterne af det nye højkvalitetsinterventionsprogram VIDA (Vidensbaseret indsats for socialt udsatte børn i dagtilbud 2010-2013), der er udviklet og implementeret i danske dagtilbud. Interventionen sætter fokus på alle børn, der deltager i dagtilbuddet - og altså også på socialt udsatte børn. Designet af VIDA-interventionen (som beskrives uddybende efterf $\varnothing$ lgende) leder os til at unders $\varnothing$ ge følgende forskningssp $\phi$ rgsmål: Kan tidlige dagtilbudsindsatser styrkes ved at uddanne pædagoger og ledere til at arbejde teoretisk, målrettet og systematisk med at udvikle kvalitet i dagtil- 
buddet? Og videre: kan dette gøres (som det er traditionen i Danmark) ved at lade pædagoger og ledere være fleksible og selvbestemmende i deres tilgang til at omsætte VIDA i deres lokale praksis, dvs. under hensyntagen til den specifikke børnegruppe, forældre og den kulturelle kontekst, som interventionen skal implementeres indenfor? Vores bidrag til dette er i VIDA at skabe evidens fra et relativt stort, randomiseret, kontrolleret eksperiment udført i Danmark - et land med et universelt system for dagtilbud, hvor mere end 97 \% af de 3-6-årige børn deltager. Resultater fra de to casestudier, der inddrages i de sammenfattende analyser, baseres på analyser af data fra baseline til endline opnået gennem surveys og interviewunders $\varnothing$ gelser.

\section{Livskompetencer og livschancer for alle}

VIDA-interventionen er bl.a. baseret på Heckmans teori om livskompetenceudvikling, som viser, at tidlige investeringer i kvalitet i børns liv generelt er mere gavnlige end senere indsatser. Denne teori samt dens empiriske grundlag viser desuden, at non-kognitive kompetencer - bl.a. barnets socioemotionelle kompetencer - kan фge dets kognitive færdigheder senere i livet. Dette taler for, at tidlige indsatser i barndommen må fokusere på både at styrke børns nonkognitive kompetencer og deres senere udvikling af kognitive kompetencer og færdigheder, som tilsammen udgør det grundlag og de ressourcer, som barnet kan trække på senere hen i livet. Det, der bliver samfundets opgave, er derfor at udvikle relevante indsatser, der kan realiseres under de givne-også фkonomiske - omstændigheder, og implementere dem i så stor skala som muligt, hvis målet er, at alle børns livschancer skal styrkes.

Socialpsykologiske og sociologiske teorier peger i samme retning. En teori om livskompetenceudvikling kan således også forstås på basis af en sociokulturel teori om individuel læring og udvikling, fx Vygotsky, kompletteret af en bio$\varnothing$ kologisk teori, fx Bronfenbrenner. Disse teorier bidrager til at forklare de komplekse sammenhænge, der er mellem de sociale systemer, som barnet er en del af: familien (mikrosystemet), uddannelsesinstitutioner og interaktioner mellem barn og voksne i institutioner såsom vuggestuer, børnehaver og skoler (mesosystemet) og samfundet (makrosystemet). Børns læring og udvikling finder sted i disse komplekse sammenhænge, og udviklingen er desuden knyttet til samspillet mellem genetiske og miljømæssige faktorer, mellem individets kognitive og non-kognitive kompetencer og mellem tidlig og senere interventioner.

Ifølge den Vygotsky-inspirerede teoretiske tilgang, som anlægges her, udvikles non-kognitive og kognitive kompetencer via 1) børnerettede mål og læringsori- 
enterede aktiviteter, som stimulerer barnets udviklingsmæssige progression, 2) responsive interaktioner mellem barn og voksen, som $\varnothing$ ger barnets evne til at tage kontrol over indre og ydre omgivelser (selvkontrol) og til at indgå konstruktivt i sociale relationer med andre, både børn og voksne og 3) socialt beskyttende og omsorgsfulde omgivelser, dvs. inkluderende læringsmiljøer, som indebærer, at der etableres samspil mellem barn og voksen, der fungerer på en sådan måde, at barnets evne til at reflektere, argumentere og kommunikere styrkes. Overordnet stimuleres barnets stadige progression hen imod $\varnothing$ get selvkontrolleret læring gennem sådanne reflekterende diskurser, som initieres af den voksne med henblik på i større og større grad at involvere barnet $i$ at tage initiativer, kommunikere, kommentere på og udveksle idéer. Sådanne sammenhængende diskurser mellem barn og voksen anses for at være afgфrende bidrag til barnets sociale udvikling - og sideløbende hermed bidrag til dets kognitive udvikling.

Dette udviklingsmæssige flow medfører en vedvarende udviklingsproces frem imod selvregulering, og som set i Heckmans teori om livskompetencer afhænger den menneskelige udvikling af, at socioemotionelle og kognitive kompetencer bringes i spil på samme tid gennem udviklingsprocessen. Desuden peger teorierne på, at det er interaktionen mellem barn og voksen - og denne interaktions kvalitet, stabilitet og intensitet - der bliver afgфrende for børns udvikling af livskompetencer. Baseret på de nævnte teorier giver det således mening at måle effekter af VIDA-interventionen både på børns socioemotionelle udvikling ved at bruge Strengths and Difficulties Questionnaire (SDQ) og på kognitive mål.

\section{Hvad ved vi fra forskning om effekter af dagtilbudsindsatser?}

Den internationale litteratur om effekter af tidlige dagtilbudsindsatser, fx den engelske 'Early Childhood Education (ECE)' består af flere senere surveys ${ }^{1}$. Meget af den fundne evidens er imidlertid baseret på små interventioner, som er rettet specifikt mod udsatte børn, og på studier gennemført som randomiserede, kontrollerede eksperimenter, hvor de deltagende børn er udtrukket tilfældigt. Det gælder amerikanske studier såsom 'Perry Pre-School'-projektet, 'Carolina Abecedarian'-projektet og 'Tool of the Mind'-projektet. Evalueringer af sådanne modelprogrammer finder, at der er positive effekter af interventionerne, og fastslår derved, at det er muligt gennem tidlige interventioner at fremme børns udvikling af socioemotionelle kompetencer og kognitiv udvikling.

1 For henvisninger til litteraturen bag denne skitserede forskningskortlægning henvises til publikationen Jensen, B., Jensen, P. \& Rasmussen, A.W. (2013). VIDA-forskningsrapport 1. Effekter af VIDA. I: VIDA-forskningsserien 2013:04. 
En anden gren af litteraturen unders $\emptyset$ ger effekter af omfattende offentligt finansierede interventioner, som fx det amerikanske 'Head Start'. I reviews konkluderes, at den eksisterende evidens fra modelprogrammer og 'Head Start' antyder, at socialt udsatte børn får mere gavn af den tidlige indsats, end andre børn gør. Dette sidste skal selvfølgelig også ses i sammenhæng med, at de ofte sammenlignes med børn, der slet ingen indsats eller st $\varnothing$ tte får i samfund, der ikke har samme universelle tilgang til dagtilbud, som vi bl.a. har i Danmark og andre nordiske lande.

Førstnævnte, de mest udsatte børn, har ikke de samme forudsætninger, når de starter i dagtilbuddet, som andre, mere privilegerede børn har med sig fra familien. Desuden risikerer dagtilbuddets hverdagsliv og aktiviteter at rumme risiko for, som også vist i Social arv-forskningsprogrammet fra 1999-2005, at der er mekanismer på færde, som ekskluderer børn, som kommer fra udsatte familier, fx ved brug af et specifikt curriculum, bestemte uddannelses- og dannelsesmæssige og kulturelle værdier og et deraf afledt sprog og sprogkoder, som mere henvender sig til middelklassens børn.

Flere studier har de senere år fokuseret på langtidseffekter og viser også betydningen af Early Childhood Education and Care (ECEC) for senere livschancer. I relation til vores studie af VIDA, som fokuserer på virkninger af professionelles kvalificeringsprocesser, er der ikke i samme grad fundet litteratur og evidens for effekter af pædagogers kvalifikationer. Dette forskningsfelt er således underbelyst både i USA og andre internationale sammenhænge samt i Norden. Vi forventer på baggrund af et review fra USA, at professionel kvalificering er altafgørende for daginstitutioners betydning for børns udvikling. I Danmark har der tidligere kun været gennemf $\varnothing$ rt ét relativt stort, randomiseret, kontrolleret eksperiment rettet mod dagtilbud. Resultaterne fra HPA-projektet indikerede en generelt positiv effekt, men demonstrerede også, at det var vanskeligere at påvirke de allermest udsatte børn, og at netop den professionelle udvikling er underlagt en del udfordringer.

Vi har også unders $\varnothing$ gt litteraturen om forældreprogrammers betydning som baggrund for at designe VIDA-modelprogrammets forældreinvolverende del. Et systematisk litteraturreview gennemf $\varnothing$ rt for VIDA-projektet har identificeret 13 effekive programmer, som sætter forældreinddragelse i fokus i interventionen².

2 Reviewet kan læses i sin helhed i rapporten Larsen et al. (2011). Programmer for 0-6-årige med forældreinvolvering i dagtilbud. En forskningskortlægning. I: VIDA-forskningsserien 2011: 02. I denne rapport er endvidere bragt en oversigt over samtlige programmer, der er gennemgået og hentet inspiration fra til udvikling af VIDA-programmet (ibid., s. 162 ff.). Undtaget dog programmet "Tools of the Mind", der ikke indgik i reviewet om forældreprogrammer. 
De samlede resultater af dette review har vi sammenfattet i nogle hovedpointer, som er indbygget i VIDA-Basis +-forældreprogrammet i det omfang, programmernes tilgang antages at kunne implementeres i en dansk kontekst, hvor indsatsen skal kunne omsættes for alle forældre og ikke kun for de socialt udsatte forældre, som de amerikanske programmer især har haft som målgruppe.

\section{Betydning af professionel kvalificering}

Der er således megen inspiration at hente i de internationale programmer, når det gælder viden om, hvad der virker i indsatser, der er målrettet de mest udsatte børn. Der savnes til gengæld som nævnt specifik viden om betydningen af professionel kvalificering. Vi har i et review (Pianta et al., 2009) fundet indikationer på, at pædagogers kvalifikationer og professionelle kvalificering er helt centrale aspekter af en succesfuld indsats i dagtilbud og mere specifikt i interventionsprogrammer. Endvidere peger forskerne bag dette review på, at dette er et hidtil underbelyst område inden for førskoleforskningen.

På andre områder, fx i skoleverdenen, er det imidlertid identificeret, at professionelles målrettede og systematiske analyser i arbejdet højner elevers udbytte af skolegang og uddannelse, og i visse tilfælde er effekter af sådanne tiltag evalueret. Det gælder fx Hattie (2008), der gennem sit review af 800 metastudier unders $\varnothing$ gte effekter af interventioner, der var designet til at fremme skoleb $\varnothing$ rns akademiske præstationer. Disse studier drejede sig først og fremmest om effekter målt på børns udbytte af skolen, hvor målgruppen var børn fra seks år. Hattie fandt, et der opnåedes de største effekter, når læreren fik muligheder for løbende at evaluere børnenes progression. Hattie beskriver "formativ evaluering" som de aktiviteter, der indebærer, at læreren systematisk måler læreprocessen og ændrer sine undervisningsformer løbende, så de tilpasses den enkelte elevs behov og inddrager forhold i læringssituationen, som evalueringen udpeger. Han finder 138 studier, der påviser positive effekter af denne tilgang til undervisning.

Grundidéen i den formative evaluering er, at processen starter med, at den professionelle (læreren) unders $\varnothing$ ger aspekter af den eksisterende praksis, hvorefter nye tilgange afprøves. Virkninger af disse tiltag unders $\varnothing$ ges $l \varnothing$ bende, og baseret på alternative tilgange og teorier afprøves nye læreprocesser rettet mod børn. Siden 1980'erne er dette kvalitetsudviklingskoncept blevet advokeret af uddannelsesinstitutioner, og hele konceptet kan videref $\varnothing$ res i en tænkning om organisatorisk læring, som er det koncept, VIDA-programmet bygger på. 
Denne tænkning om organisatorisk læring drejer sig nemlig om, at professionelle uddannes og trænes til at arbejde med fornyelse af pædagogisk praksis gennem brug af refleksion, unders $\varnothing$ gelse, afpr $\varnothing$ vning, testning og evaluering. Derved udvikler professionelle nye måder at løse aktuelle problemstillinger i praksis på, som er det helt centrale i VIDA-projektet. Dette perspektiv er endvidere inspireret af forskning i innovation i offentlige og private virksomheder, som finder, at det er i kombinationen af et top-down- og et bottom-up-perspektiv, at den største chance for virkelig at skabe udvikling, der virker, opstår (effekt). Det er essentielt, at processen tager udgangspunkt i aktuelle praksisser snarere end i teori, men omvendt er det også påvist, at det at bygge nye initiativer op på en kombination af to vidensformer, en praksisbaseret og en forskningsbaseret, i processen er effektivt, når målet er at skabe innovation. Sådanne eksempler på kvalitetsforbedringer og innovation har vi ikke fundet i førskoleforskningen, men det antages, at en tilsvarende tilgang vil kunne bidrage i udviklingen af nye former for pædagogisk innovation, som er det, vi i VIDA-programmet har afprøvet og evalueret effekterne af.

Teoretisk er VIDA-interventionsprogrammet sammenligneligt med andre, tidligere interventionsprogrammer, men især er programmet 'Tool of The Mind' (TOM) inspirationskilde. Dette program finder nemlig, at der opnås positive effekter ved at bygge interventionen på Vygotskys teori om, at børns trivsel og læring fremmes gennem stimulerende, responsive interaktioner mellem voksen og barn. TOM-programmet bygger på den tese, at børns udvikling fremmes, hvis man arbejder ud fra en teori om samspil mellem genetiske og miljømæssige faktorer, mellem kognitive og socioemotionelle kompetencer og kreative læreprocesser og mellem tidlig og senere indsats.

Opsummerende udgør de gennemgåede internationale programmer og studier af betydningen af professionel kvalificering fundamentet for VIDA-programmet. I det $f \varnothing l g e n d e$ sammenfattes det koncept og de perspektiver, som VIDA-interventionsprogrammerne bygger på, som følge af det aktualiserede samfundsmæssige behov for at udvikle en ny, innovativ form for indsats i dagtilbud, der kan implementeres under de betingelser, som er skitseret indledningsvis.

\subsection{ET SAMLET VIDA-KONCEPT}

VIDA lægger op til en innovativ tilgang til nye former for forebyggende indsatser i dagtilbud. Konceptet er bygget over begrebet social innovation, som defineres som varig fornyelse med værdiforøgelse for de deltagende børn som mål. I VIDA omfatter fornyelsen følgende tre perspektiver: 
- $\quad$ Fra fejlfindings- til ressourcesyn (børne- og problemsyn)

- $\quad$ Fra et passivt til et aktivt læringsbegreb (børn og voksne) og

- $\quad$ Fra et individuelt til et organisatorisk læringsperspektiv.

Dertil kommer, at kriteriet for, at man som deltager holder sig til den fælles konceptuelle ramme, dvs. arbejder med VIDA ud fra dets intentioner, er, at de professionelle arbejder vidensbaseret, målrettet og systematisk samt dokumenterbart. De tre aspekter viden, refleksion og handlinger er således forudsætninger for implementering af programmets tre perspektiver.

Det første perspektiv i denne konceptualisering af programmet kan kaldes ressourceperspektivet. Dette anlægges som det fundamentale udgangspunkt for indsatsen og tager afsæt i viden, der bl.a. blev identificeret i forskningsprogram om social arv (2005), der viste, at dagtilbud ofte bygger indsatser op på en tænkning om 'fejlfinding'. Som noget centralt i VIDA-projektet rettes de to modelprogrammer VIDA-Basis og VIDA-Basis + mod at kvalificere professionelles arbejde med udsatte børn med fokus på to mål: 1) For det første det individuelle mål, som drejer sig om at fremme børns trivsel, læring og udvikling ved at satse på både børns kognitive og socioemotionelle kompetencer og på at skabe en forbedret pædagogisk indsats og konkrete aktiviteter, der st $\varnothing$ tter dette dobbelte individuelle mål, og 2) for det andet det kontekstuelle mål, som drejer sig om at skabe inkluderende pædagogiske læringsmiljøer i dagtilbuddet. I VIDA-Basis +-programmet arbejder deltagerne desuden med nye metoder til inddragelse af forældre. Ved at anlægge dette dobbelte perspektiv, sammenhængen mellem det individuelle og det kontekstuelle, tages der samtidig afstand fra at arbejde ud fra et 'fejlfindingssyn', og intentionen er overordnet at søge nye veje ud fra et ressourcesyn.

Det andet perspektiv kan kaldes et aktivt læringsperspektiv. Dette perspektiv drejer sig om, at VIDA-programmet udvikler og afprøver en intervention, hvor kvalificering af professionelle gennem et uddannelses- og implementeringsforløb baserer sig på en teori om betydningen af, at deltagerne er aktivt lærende gennem hele forl $\varnothing$ bet. Teoretisk, forskningsbaseret og erfaringsbaseret viden er de tre vidensformer, der sættes i spil på VIDA-uddannelsen. Det er afgørende, at professionelle uddannes til systematisk at arbejde med viden, refleksion og handlinger $\mathrm{i}$ alle processer for at kunne skabe en nødvendig fornyelse af praksis på et vidensbaseret grundlag, som er hele VIDA-programmets omdrejningspunkt. Perspektivet om aktiv læring betyder, at pædagoger og ledere lærer at omsætte et fælles vidensgrundlag i form af materialer og værktøjer lokalt, og at 
der arbejdes målrettet med handlinger i praksis ${ }^{3}$. Denne samlede læringsproces tager udgangspunkt i et uddannelsesforl $\varnothing \mathrm{b}$ og et samarbejde med kommunerne

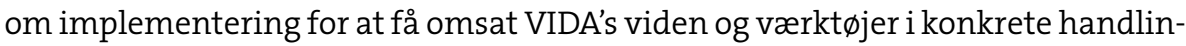
ger og eksperimenter i praksis ${ }^{4}$.

Det tredje perspektiv kan kaldes et organisationsperspektiv. For at kunne skabe nye pædagogiske praksisser kræver det, at alle i dagtilbuddene arbejder sammen om forandringerne, og organisatorisk læring er som sådan et af nøglebegreberne i VIDA-projektets læringsperspektiv. VIDA-forskningsprogrammet unders $\varnothing$ ger effekten af, at pædagogiske medarbejdere uddannes og trænes i systematisk at arbejde med viden, videndeling og kritisk refleksion i den samlede organisation. Forskningsprogrammet yder derfor også et væsentligt bidrag til at belyse, hvorvidt og hvordan det er muligt at skabe samlede organisationsforandringer i danske dagtilbud med det fælles mål at stå op imod konsekvenser af social arvproblematikker 5 .

Foruden de tre nævnte perspektiver har der været lagt vægt på et fjerde og sidste perspektiv i forskningsprogrammet, som kaldes brugerperspektivet. Det er som i det tidligere nævnte forskningsprogram om social arv og forskningsprojektet HPA helt afgørende i VIDA at tænke brugere ind i programmet fra starten. I VIDA har vi gjort det ved løbende at afholde konferencer, start-, midtvejs- og slutkonference rettet mod politikere, kommuner, professionelle grupper i socialforvaltningerne, PPR, daginstitutions- og skoleverdenen, SSP, således at resultater og delresultater kommer de nævnte grupper til gode, ikke bare afslutningsvis, men også løbende. Således har VIDA-programmet bidraget allerede inden dets afslutning til diskussioner, inspiration og videreudvikling af feltet. Vi har endvidere udgivet publikationer løbende og formidlet via VIDA-hjemmesiden. På hjemmesiden bliver alle materialer, publikationer og værkt $\varnothing$ jer ligeledes gjort offentligt tilgængelige ved projektafslutning6 ${ }^{6}$

3 Nærmere beskrivelser af VIDA-programmernes materialer og værkt $\varnothing j e r$ findes i Bente Jensen (red.) (2013). VIDA-modelrapport 1. Materialer og værktøjer. I: VIDA-forskningsserien 2013:01.

4 Nærmere beskrivelse af VIDA-programmernes uddannelses- og implementeringsforl $\varnothing \mathrm{b}$ findes i Kristina Kristoffersen (red.) (2013). VIDA-modelrapport 2. Uddannelse og implementering. I: VIDAforskningsserien 2013:02.

5 Nærmere beskrivelse af VIDA-programmernes eksperimenterende tilgang omsat i hele organisationen findes i Jakob Haahr-Pedersen \& Bente Jensen (red.) (2013). VIDA-modelrapport 3. VIDA $i$ praksis. I: VIDA-forskningsserien 2013:03.

6 En samlet oversigt over den samlede 'VIDA-værkt $\varnothing$ jskasse' findes som Bilag 4 i VIDA-modelrapport 1 samt på VIDA-Websitet: http://edu.au.dk/forskning/projekter/vida/ 


\subsection{VIDA-PROGRAMMET}

VIDA-interventionen har som mål at fremme alle børns sociale kompetencer og læring - med særligt fokus på socialt udsatte børn. Det samlede projekt er designet som et randomiseret, kontrolleret eksperiment, og målgruppen er alle børn i udvalgte dagtilbud (i alt 7.000 børn).

Metodisk adskiller VIDA-programmet sig fra de gennemgåede internationale programmer ved, at det først og fremmest er pædagogers kvalificering, der sættes i centrum for interventionen. Til forskel fra tidligere programmers korte workshops og kurser for professionelle, som gennem instruktion oplærer de professionelle i at $f \varnothing$ lge programmets forskrifter og metoder, tilbydes de professionelle, der deltager i VIDA, et uddannelses- og træningsforl $\varnothing \mathrm{b}$, som strækker sig over længere tid, hvor undervisning veksler med lokale udviklingsforløb med henblik på at træne professionelle i at analysere, reflektere over og evaluere egne aktiviteter rettet mod at styrke børns læring, trivsel og udvikling.

VIDA-Basis +-forældreprogrammet er i høj grad inspireret af de internationale programmer, da vi ikke i Danmark hidtil har haft tradition for at arbejde så målrettet med forældreinddragelse som en del af dagtilbuddets opgaver. Til forskel fra de tidligere programmer er VIDA-Basis +-forældreprogrammet rettet mod at styrke børns udvikling gennem $\emptyset$ get kvalitet og bedre samarbejdsformer med forældrene. Ligeledes til forskel fra de amerikanske programmer går man i VIDA ikke ud i hjemmene eller arbejder med forældreuddannelse og -evner. Inspireret af Bronfenbrenners teori forventes det, at en intervention, der ud over at styrke børns læring, trivsel og udvikling også styrker relationer mellem familien (mikrosystemet) og institutionen (mesosystemet), yderligere vil kunne styrke effekter af interventionen. Dette er ikke påvist i andre interventionsstudier, men afpr $\varnothing$ ves således i VIDA.

HPA-projektets erfaringer med at sætte professionel kvalificering i centrum videreføres i VIDA. Når det er sagt, skal det understreges, at vi har ændret uddannelsesforl $\varnothing$ bet i VIDA, så der sættes større fokus på, at deltagerne arbejder med guidelines, materialer og værkt $\varnothing$ jer, som kan underst $\varnothing$ tte implementeringsprocessen og derved intensivere den professionelle udvikling og kvalificering af de deltagende ledere og pædagoger fra hver institution. Endvidere har vi i VIDA udviklet lederkurser, der træner lederne i at lede organisatoriske læreprocesser. Endelig er der lagt stor vægt på et yderligere systematiseret og formaliseret samarbejde med kommunernes forvaltninger, dagtilbudschefer og konsulentniveauet. Dette skyldes bl.a., at vi fra forskningen ved, at det at sikre deltagerne 
support og træning og/eller coaching vil kunne styrke deltagerne mere konkret i at implementere interventionen. Derfor har vi fors $\varnothing$ gt at lægge op til en st $\varnothing$ rre grad af support og/eller coaching fra kommunale konsulenter på baggrund af samarbejdsaftaler mellem projektets ledelse og kommunernes dagtilbudschefer.

Opsummerende udgør de gennemgåede internationale programmer og studier sammen med positive erfaringer fra HPA-projektet omkring det at fremme professionel kvalificering fundamentet for VIDA-programmet, der skal kunne implementeres under følgende betingelser:

1. indsatsen skal være for alle børn, da $97 \%$ af alle danske 3-6-årige børn er i dagtilbud fra 3-årsalderen

2. indsatsen skal fremme børns trivsel og læring i bredt perspektiv som angivet i det nationale curriculum (Bekendtgørelse om pædagogiske læreplaner, Scialministeriet, 2004)

3. indsatsen skal gennemføres af professionelle, som i forvejen arbejder i dagtilbuddet, (dvs. ikke af specialister, men af en blanding af pædagoger med professionsbachelorgrad og ikke-uddannede medarbejdere, som har tradition for at arbejde med stor autonomi i det daglige pædagogiske arbejde).

Skønt vores studie af VIDA-interventionens effekter fokuserer på korttidseffekter, er det værd at nævne, at vi også henter vigtig inspiration i de skandinaviske storskalastudier, der demonstrerer, at universaldagtilbudssystemet rent faktisk påviser positive langtidseffekter. Det interessante er i den sammenhæng, at pædagogers kvalifikationer ser ud til at være positivt forbundet med børns udbytte. Det er dette forhold, som VIDA-programmet vil unders $\emptyset$ ge nærmere.

Formålet med VIDA-modelprogrammet er som nævnt at udvikle, implementere og unders $\varnothing$ ge effekterne af en ny metode til at styrke tidlige indsatser i dagtilbud. Mere specifikt er målet med VIDA-interventionen at opkvalificere pædagoger og lederes kompetencer gennem et uddannelses- og træningsforl $\phi b$, der gør deltagerne på VIDA-uddannelsen i stand til at arbejde målrettet og systematisk med læring og videndeling i den samlede organisation (dagtilbuddet), hvilket indebærer, at alle pædagogiske medarbejdere inddrages i at skabe kvalitetsudvikling i praksis. VIDA-programmernes tilgang medfører, at frem for at give instruktion i hvordan pædagogerne skal omsætte en bestemt metode i hverdagen, inviteres medarbejderne i de deltagende dagtilbud til at udvikle og forny deres pædagogiske praksis lokalt - baseret på de præsenterede teorier, metoder, værkt $\varnothing$ jer og guidelines, som er udviklet til VIDA. Denne model for intervention er begrundet i, at der i VIDA tages højde for, at programmet skal implementeres i universaltil- 
bud, målrettes den specifikke situation, dvs. de udfordringer og den børnesammensætning, som g $\varnothing \mathrm{r}$ sig gældende i den pågældende institution, og gennemføres af professionelle, som har tradition for at arbejde selvstændigt og med stor autonomi i hverdagen.

I det følgende præsenterer vi mere detaljeret curriculum for VIDA-Basis-programmet og for VIDA-Basis +-forældreprogrammet samt strategien for professionel udvikling, som ligger i VIDA-programmet. Afslutningsvis opsummerer vi ved hjælp af en model for den samlede interventions- og effektmålingsstrategi.

\section{Curriculum for VIDA-Basis og VIDA-Basis +}

VIDA-interventionen består af de to modelprogrammer; VIDA-Basis- og VIDABasis +-forældreinddragelse. VIDA-Basis-programmet sigter mod at styrke alle børns trivsel, læring og udvikling, mens VIDA-Basis +-programmet foruden en satsning på børns trivsel, læring og udvikling også inddrager involvering af forældrene. De to programmer beskrives mere detaljeret nedenfor.

\section{VIDA-Basis}

VIDA-Basis-interventionen implementeres af medarbejdere i de deltagende dagtilbud, som arbejder med nye handlinger og rutiner baseret på VIDA-programmets guidelines og værkt $\varnothing j e r$. Programmet er baseret på socialpsykologiske og sociologiske teorier om, hvad der fremmer børns læring og udvikling, fx Vygotsky kompletteret af en bio- $\varnothing$ kologisk teori. Disse teorier forklarer de komplekse sammenhænge mellem de sociale systemer, som barnet er en del af: familien (mikrosystemet), uddannelsesinstitutioner og interaktioner mellem barn og voksne $\mathrm{i}$ institutioner såsom vuggestuer, børnehaver og skoler (mesosystemet) og samfundet (makrosystemet). Børns læring og udvikling finder sted i disse komplekse sammenhænge, og udviklingen er desuden knyttet til samspillet mellem genetiske og miljømæssige faktorer, mellem kognitive og non-kognitive kompetencer og mellem tidlige og senere interventioner.

Ifølge den Vygotsky-inspirerede teoretiske tilgang, som anlægges her, udvikles socioemotionelle og kognitive kompetencer via 1) børnerettede mål og læringsorienterede aktiviteter, som stimulerer barnets udviklingsmæssige progression, 2) responsive interaktioner mellem barn og voksen, som $\emptyset$ ger barnets evne til at tage kontrol over indre og ydre omgivelser (selvkontrol) og til at indgå konstruktivt i sociale relationer med andre, både børn og voksne, og 3) socialt beskyttende og omsorgsfulde omgivelser, dvs. inkluderende læringsmiljøer, som indebærer, at der etableres samspil mellem barn og voksen, der fungerer på en sådan måde, 
at barnets evne til at reflektere, argumentere og kommunikere styrkes. Overordnet stimuleres barnets stadige progression hen imod øget selvkontrolleret læring gennem sådanne reflekterende samtaler, som initieres af den voksne med henblik på mere og mere at involvere barnet i at tage initiativer, kommunikere, kommentere på og udveksle idéer. Sådanne sammenhængende diskurser mellem barn og voksen anses for at være afgørende bidrag til barnets sociale udvikling og sideløbende hermed bidrag til dets kognitive udvikling.

Vygotsky beskriver progressionen i børns læring som en proces, hvorved interpsykologiske handlinger, såsom kommunikation og sprogliggørelse, gradvist udvikles i takt med, at barnets evne til problemløsning og til at tage kontrol på det intrapsykologiske plan $\emptyset$ ges og gør barnet mere og mere uafhængigt af andre (dvs. ydre tale udvikles gennem interaktioner med andre til tanker og indre tale). Dette udviklingsmæssige flow medfører en vedvarende udviklingsproces frem imod selvregulering. Set i relation til en sammenhængende teori om livskompetencedannelse afhænger den menneskelige udvikling af såvel socioemotionelle som kognitive kompetencer, og begge anses for at være i spil på samme tid gennem udviklingsprocesser.

Sammenfattende underst $\varnothing$ tter dette teoretiske grundlag, at det er interaktionen mellem barn og voksen og barnet og andre børn og denne interaktions kvalitet, stabilitet og intensitet, der bliver afgørende for barnets udvikling af socioemotionelle kompetencer samt for sideløbende kognitive kompetencer, herunder sproglig og kommunikativ udvikling samt identitet. Det er også interaktionen og dennes kvalitet, der er af afgørende betydning for barnets udvikling af evne til at tænke og for dets motivation for at lære, unders $\varnothing$ ge og reflektere kritisk og analytisk.

Alle aktiviteter sker i VIDA i inkluderende læringsmiljøer, og de forventet stærkeste drivkræfter bag børns læring og udvikling af trivsel er: 1) vokseninitierede og velorganiserede læringsaktiviteter med et stort udvalg af temaer baseret på det nationale curriculum (pædagogiske læreplaner), fx socioemotionel og personlig kompetenceudvikling, sprog, literacy og kommunikation, fysisk udvikling, matematisk forståelse, forståelse for science og teknologi, kreativitet gennem kunst og kultur og interesse i at lære, 2) barneinitierede læringsaktiviteter, der udforsker de samme temaer, også baseret på det nationale curriculum (pædagogiske læreplaner), 3) underst $\varnothing$ ttende aktiviteter, som træner børns sprog og fysiske færdigheder i fællesskaber med andre børn, 4) stimulering af børns læring og trivsel gennem aktiv involvering, 5) stimulering af børns nysgerrighed og kon- 
centration gennem lærende lege og spil samt 6) undersøgelse af børns progression i dagligdagen gennem VIDA-refleksionsværkt $\varnothing$ jet og baseret på værkt $\varnothing$ jets analyser at opfordre børn til at være udforskende i relation til børnefællesskaber og til selvstændigt at gå i gang med nye aktiviteter.

Disse metoder og værkt $\varnothing$ jer, som i VIDA er tilbud, er ikke at betragte som en på forhånd fastlagt metode, der fx angiver præcist, hvor ofte, hvor længe eller hvordan det valgte tema skal indgå som aktivitet. Derimod angiver programmets guidelines og værktøjer, hvordan aktiviteterne tilrettelægges, begrundes, og hvordan de implementeres som en fortløbende proces, der både rummer guidelines til organisering, tilrettelæggelse og gennemf $\varnothing$ relse af aktiviteten samt til evaluering, så det sikres, at pædagogen med den valgte aktivitet unders $\varnothing$ ger, om aktiviteten tager højde for det enkelte barns behov og forudsætninger og giver de $\varnothing$ nskede virkninger, som de kan konstateres lokalt. Samtidig tages der højde for de specifikke sociale relationer og udfordringer, der kan være til stede i den enkelte børnegruppe og i det enkelte dagtilbud. Ledere og pædagoger i VIDAprogrammet uddannes på den måde til målrettet og systematisk at arbejde med pædagogiske praksisser, der styrker børns ressourcer i et livskompetenceperspektiv.

Kvalifikationsstrategien i VIDA for ledere og pædagogiske medarbejdere består af et uddannelses- og træningsprogram, som anvender en vidensbaseret tilgang til implementering af VIDA-modelprogrammerne i praksis. Alle deltagere (en leder og en pædagogisk medarbejder fra hver daginstitution) er tilbudt i alt 17 uddannelsesgange (syv hele uddannelsesdage om året i to år og tre praksisbaserede sessioner det sidste år) og dertil muligheder for at deltage i en workshop for alle deltagere i VIDA-programmerne afholdt lokalt i de fire kommuner hvert af de to år. Derudover er alle ledere tilbudt et todages kursus inklusive workshops (internat) hvert af de to år med undervisning i facilitering af læreprocesser som forudsætning for implementering af programmerne i den samlede institution. Også dette er baseret på et princip om organisatorisk læring7.

Et vigtigt redskab for de organisatoriske læringsprocesser er kritiske refleksionsgrupper. Et vigtigt fokuspunkt i interventionen er at sikre deltagerne muligheder for at skabe sammenhæng mellem den enkelte medarbejders tilegnelse af det anlagte teoretiske grundlag, den forskningsbaserede viden og integration af denne viden i den samlede organisation, daginstitutionen. Dette sker fx ved, at

7 For en nærmere beskrivelse af uddannelsesforl $\varnothing \mathrm{b}$ og implementeringsst $\varnothing$ tte henvises til publikationen Kristoffersen et al. (red.) (2013). VIDA-modelrapport 2. Uddannelse og implementering. I: VIDA-forskningsserien 2013:02. 
leder og pædagog, der har været på VIDA-uddannelsen, introducerer nye aktiviteter og arbejdsmåder som oplæg til fælles refleksion over og analyser af, hvordan de nye aktiviteter virker i praksis. Organisatorisk læring sker, når medarbejderne tilegner sig ny viden og anvender denne til at forandre de arbejdsrelaterede praksisser, evaluerer disse og sikrer, at disse systematisk indarbejdes og praktiseres af alle medarbejdere i daginstitutionerne ${ }^{8}$. På det teoretiske plan er det antagelsen, at opkvalificering af professionelles kompetencer bedst opnås ved denne form for uddannelse og træning, der fremmer organisatorisk læring, refleksion og aktive, skabende medarbejdere, der i fællesskaber udvikler nye praksisser. Denne tilgang er baseret på studier af professionel udvikling, organisatorisk læring og innovation i den offentlige sektor samt forskning i praksisbaseret innovation.

\section{VIDA-Basis +-forældreprogrammet}

VIDA-Basis +-interventionsprogrammet er grundlæggende det samme som VIDA-Basis-programmet, hvad angår det indholdsmæssige, men med et supplerende forældrefokus.

VIDA-Basis +-forældreprogrammet inkluderer følgende aspekter: 1) aktiv forældreinvolvering, hvilket bl.a. indebærer, at forældrene tilbydes/foreslås at gennemføre konkrete aktiviteter hjemme, som er relateret til de lærings- og udviklingsaktiviteter, som finder sted for børnene i daginstitutionen, og 2) kurser og fælles refleksion: forældre deltager i sammenhænge, der lærer dem aktiviteter, som de kan udføre med deres barn. Der er lagt op til, at møder om sådanne aktiviteter i grupper med andre forældre fx finder sted hver måned i den enkelte daginstitution. Assisteret af pædagog og/eller leder får forældrene derved muligheder for at få viden og reflektere over disse aktiviteter gennem nye former for forældresamarbejde, og i forbindelse med forældrekaffe, fællesspisning eller kurser for forældrekredsen tilbydes forældre ny viden om børns læring og udvikling af socioemotionelle kompetencer, personlig udvikling og kognitive kompetencer. Forældrene opfordres til at igangsætte lignende aktiviteter med deres b $\varnothing$ rn hjemme i perioden mellem de formelle og mere uformelle møder i daginstitutionen.

Som et eksempel arbejdede en specifik daginstitution i en måned med begrebet følelser baseret på en såkaldt følelsesmappe, som var udviklet specifikt til aktiviteten. I mappen var der sat billeder ind af alle børnenes forskellige ansigter, som udtrykte et stort register af mange forskellige følelsesudtryk. Denne følelsesmappe blev brugt i daginstitutionen til at lære børn, hvordan de skulle udtrykke,

8 For konkrete eksempler henvises til publikationen Jensen, B. \& Haahr-Pedersen, J. (red.) (2013). VIDA-modelrapport 3. VIDA i Praksis. I: VIDA-forskningsserien 2013:03. 
forklare og forstå egne og andres følelser. Mappen blev også givet til forældrene som en opgave, de kunne tage med hjem og arbejde videre med og derved arbejde med den samme aktivitet som institutionen, der som mål havde at styrke børns socioemotionelle udvikling (trivsel). Idéen med dette eksempel er at vise, hvordan læringsaktiviteter i daginstitutionen kan suppleres med lignende aktiviteter hjemme.

Det overordnede mål med disse aktiviteter er at generere $\varnothing$ get forældrekompetence gennem vejledning, samarbejde, followup, supervision og evaluering af specifikke aktiviteter, hvor forældre opmuntres til at udf $\varnothing$ re en række aktiviteter hjemme og derved matche det, der foregår i dagtilbuddet, hvilket skaber sammenhæng for børnene.

\section{Professionel kvalificeringsstrategi}

I VIDA uddannes og trænes pædagoger og ledere som nævnt i at skabe kvalitetsudvikling og varig værdiforøgelse i det samlede dagtilbud. De aktiviteter, der sættes i gang, tager udgangspunkt i VIDA-guidelines, -materialer og -værkt $\varnothing$ jer, som alt sammen introduceres på uddannelsen og afprøves i lokale praksisforl $\varnothing$ b. VIDA-uddannelsen består således både af undervisning og procesledelse, reflek-

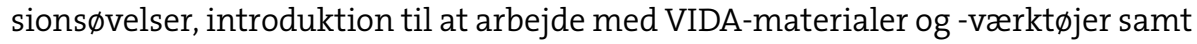
et træningsprogram specifikt for lederne. Det samlede interventionsprogram i VIDA består overordnet af tre elementer: viden, refleksion og handling, som veksler med hinanden i det toårige interventionsforl $\varnothing b$ og gennem den række uddannelses- og workshopforl $\varnothing b$, som deltagerne tilbydes (se figur1).

Figur 1. VIDA uddannelsesstrategi.

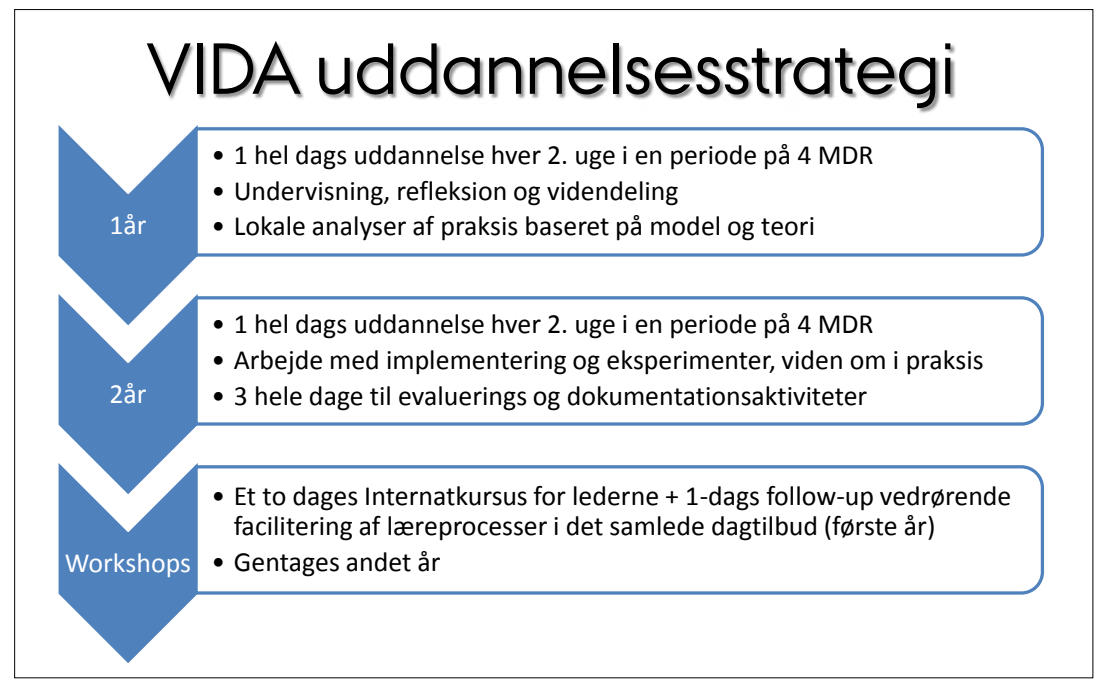


Videnselementet er som vist centralt i VIDA-projektets uddannelsesforl $\varnothing$ b. Formålet med uddannelsesforløbet er at styrke deltagernes teoretiske viden og pædagogiske faglighed og derved opbygge en fælles, forskningsbaseret "fond" af viden, som kan omsættes i fornyelse af handlinger i praksis. Alle deltagerne uddannes til at arbejde selvstændigt og i fællesskab med elementerne viden, refleksion samt handling (strategi). Disse elementer er gennemgående i hele uddannelsen, men med hver sin vægtning i forløbets faser. Perioden for professionel kvalificering forløber over to år som vist i figuren.

I første del (1. år) lægges der vægt på, at deltagerne tilegner sig forskningsviden og refleksion over egen praksis på baggrund af den præsenterede forskningsviden. Deltagerne trænes også i at dele viden fra uddannelsen med medarbejderne i det samlede dagtilbud (dvs. også de medarbejdere, der ikke deltager på uddannelsen). Undervisningsforl фbet (i alt syv hele dage) afløses af lokale analyser af praksis baseret på viden og refleksion over, hvordan viden fra uddannelsen kan anvendes, og dette sker gennem videndeling i det samlede dagtilbud. Den viden, der er omdrejningspunktet, er både dansk og international forskningsviden om, hvad der virker og påvirker i relation til social arv, socialt udsatte børn, inklusion/ eksklusion, pædagogiske læreplaner og deres anvendelse, læring i organisationer, innovation og implementering.

I anden del af forløbet (2. år) lægges der vægt på, at institutionerne omsætter refleksion over og analyse af egen praksis (ved brug af VIDA-refleksionsværkt $\varnothing j e t)$ i organisatorisk læring som forandringsprocesser i den samlede daginstitution. Undervisningsforl $\varnothing$ bet ( $\mathrm{i}$ alt syv hele dage suppleret med tre hele dage til at arbejde med eksperimenter) bidrager med uddannelse $i$, hvordan institutionen skal arbejde med udvikling af ny adfærd, nye praksisser, og i den sammenhæng undervises der konkret i arbejdet med eksperimenter - dvs. afgrænsede og målrettede aktivitetsforl $\varnothing b$, der konkret fremmer børns trivsel og læring gennem inklusion. Den eksperimenterende fase afsluttes med, at hver institution gennemfører og evaluerer en række eksperimenter (hver af en måneds varighed) . $^{9}$ Deltagerne trænes endvidere i løbende at evaluere aktiviteters virkninger på det enkelte barn, på børnefællesskaber og på udvikling i og af den samlede institution.

I tredje del af forløbet (workshops) arbejdes der med lederkurser. Her får lederne på tværs af de fire deltagende kommuner muligheder for at træne det at facilitere

9 For en beskrivelse af 12 eksempler på institutioners konkrete arbejde med eksperimenter i VIDA henvises til Jensen, B. \& Haahr-Pedersen, J. (2013). VIDA-modelrapport 3. VIDA i praksis. I: VIDAforskningsserien 2013:03. 
nye aktiviteter på måder, så alle medarbejdere (og forældre i VIDA-Basis +) inddrages. Lederne får på disse workshops mulighed for at udveksle erfaringer og idéer til arbejdet med udvikling, fastholdelse og kvalitetssikring af de forskningsbaserede fornyelser i praksis ud fra den eksperimenterende tilgang.

\section{VIDA-modelprogrammet - en samlet model for implementering og effektforskning}

VIDA-interventionens vægt på professionel kvalificering indbefatter således, at uddannelsesforl $\varnothing$ bet og implementeringsforl $\varnothing$ bet er gensidigt afhængige af hinanden. Uddannelsesforl $\varnothing$ bet sætter deltagerne i stand til at arbejde med viden, refleksion og værkt $\varnothing$ jer, der kan være med til at udvikle kvalitet med det formål at styrke alle børns trivsel og læring. Implementeringsforl $\varnothing$ bet sikrer, at VIDA-programmernes indhold (curriculum, metoder og materialer) gøres aktuelt, levende og skaber udvikling i praksis. Derfor inddrager undervisningen kontinuerligt deltagernes praksis og lægger løbende op til forskellige implementeringsprocesser i praksis, som st $\varnothing$ ttes gennem træningsforl $\varnothing b$ i facilitering for lederne. Som del af strategien for professionel kvalificering har kommunale konsulenter været inviteret med på samtlige uddannelsesforl $\varnothing$ b og har som sådan været inddraget i implementeringsprocesserne.

Formålet med VIDA-uddannelsesforløbet er således, at deltagerne erfarer og opbygger ny forskningsbaseret viden og forståelse og derved skaber nye handlemuligheder i praksis for alle børn generelt og dermed også for børn i udsatte positioner gennem pædagogikken og forældreinddragelse i VIDA-Basis +. VIDAprojektet har en grundlæggende antagelse om, at opkvalificering af de pædagogiske medarbejdere bedst sker ved, at uddannelsesforl $\varnothing$ bet underst $\varnothing$ tter organisatorisk læring, ejerskab og aktivt medskabende deltagere (Jensen et al., 2011a, s. 61). Denne antagelse baseres dels på HPA-projektet og dels på videregående studier i forskning i professionel udvikling, læring og innovation i arbejdslivet i den offentlige og private sektor (se Jensen \& Brandi, 2013, VIDA-forskningsrapport 2).

I VIDA-projektet beskrives hele idéen bag interventionen på følgende vis:

"Idéen med interventionen og de indbyggede vidensbaserede materialer og udviklingsværktøjer er, at deltagerne selv sætter fokus på at udvikle viden, refleksioner og redskaber til at arbejde med deres egen praksis. Intentionen er desuden, at deltagerne opnår viden om, hvordan den evidensbaserede viden og refleksioner kan udfoldes $i$ dagtilbuddet og danne grundlag for nye pædagogiske praksisser $i$ organisationen på måder, som involverer alle medarbejdere ". 
Uddannelse og implementering i de enkelte dagtilbud skal som nævnt ses i en sammenhæng i VIDA-programmet, da uddannelsesforl $\varnothing$ bet med sine tre faser veksler med lokale udviklingsforl $\varnothing b$, ligesom viden veksler med refleksion og handlinger i praksis, hvilket tydeliggøres her i figur $2^{10}$ :

Figur 2: En samlet model for VIDA-interventions- og -effektforskning

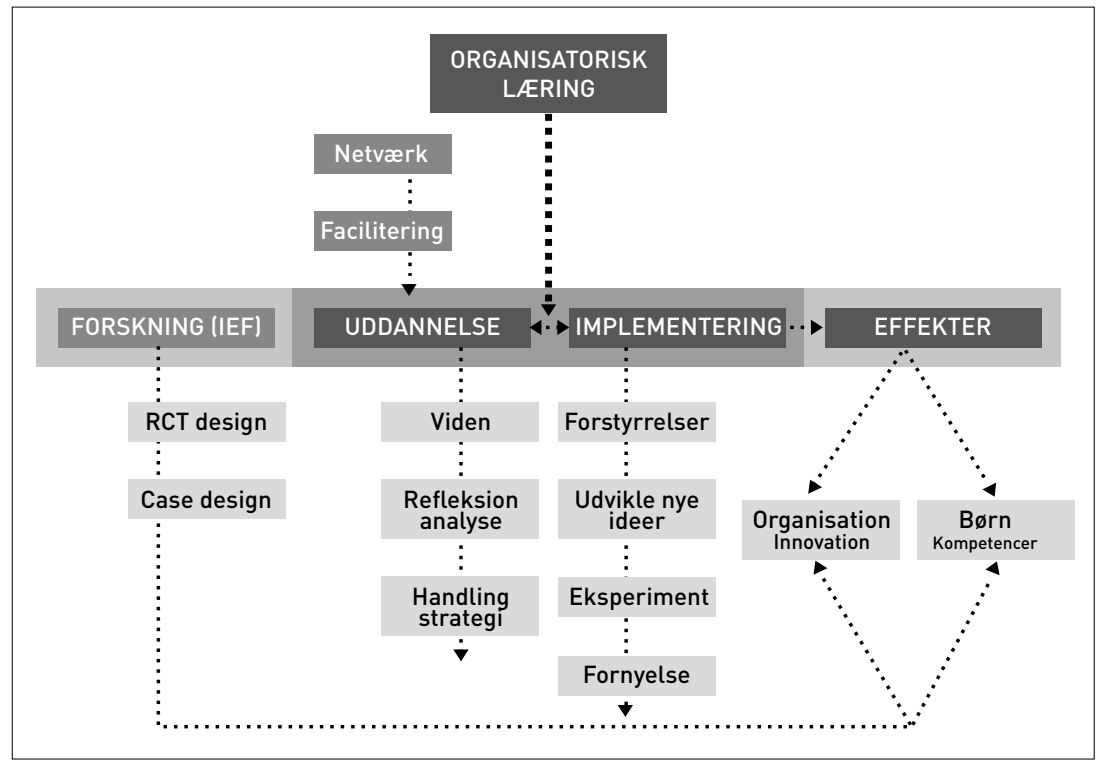

Figuren viser os samtidig, hvordan uddannelse og implementering er knyttet sammen via et fælles fokus på organisatorisk læring, hvor netværk og facilitering er vigtige elementer. Uddannelse og implementeringsprocesserne skal skabe den $n \varnothing$ dvendige organisatoriske læring, der sikrer en positiv udvikling af praksis i forhold til innovation i organisationen og børns kompetencer.

10 Figuren er hentet fra Jensen et al. (2011). VIDA-statusrapport 1, Design og metode. I: VIDA-forskningsserien 2011:01, side 43. 



\title{
VIDA-PROGRAMMETS EFFEKTER
}

\author{
- OVERORDNEDE TRFK
}

\subsection{DESIGN OG DATA ${ }^{11}$}

I VIDA-forskningsprogrammet er der gennemf $\varnothing$ rt en effektunders $\varnothing$ gelse baseret på et randomiseret, kontrolleret eksperimentdesign. Derved bliver det muligt at unders $\varnothing$ ge effekterne af VIDA-interventionsmodelprogrammet, der som beskrevet ovenfor er udviklet og implementeret i projektperioden 2010-2013.

Randomiseringen i VIDA er sket på institutionsniveau. Fire kommuner deltager i programmet, to af disse med alle dagtilbud for 3-6-årige i kommunen ${ }^{12}$. Randomiseringen er baseret på stratificering af dagtilbuddene i seks grupper klassificeret på andel socialt udsatte $b \varnothing \mathrm{rn}$. Inden for disse grupper er daginstitutioner tilfældigt udtrukket til at deltage i VIDA-Basis-, VIDA-Basis +- eller som referenceinstitution (kontrolgruppe).

VIDA startede i december 2010 med udvælgelse af kommuner. Udtræk af institutioner fandt sted januar 2011 baseret på en segmenteringsmodel, der tidligere

11 Dette kapitel baserer sig på analyser, der er lagt frem hos Jensen, B. Jensen, P. \& Rasmussen, A.W. (2013). VIDA-forskningsrapport 1. Effekter af VIDA. I: VIDA-forskningsserien 2013:04.

12 Institutioner, som er placeret i områder med mange socialt udsatte børn, får ikke flere ressourcer fra VIDA-programmet end andre institutioner. Det er imidlertid muligt, at disse institutioner får mere tilskud fra kommunerne end andre institutioner. Generelt er den totale mængde af ressourcer, der anvendes på projektet, relevant for at evaluere det samlede udbytte af programmet. Disse omkostninger relaterer sig til konsulenter, der er tildelt i de forskellige kommuner i form af konsulentst $\varnothing$ tte, frik $\varnothing$ b af medarbejdere og den lokale leder til at deltage i uddannelses- og træningsforl $\phi b$, som er allokeret til den enkelte institution, og muligvis andre udgifter, som er allokeret til deltagelse i programmet fra kommunens side. 
var udviklet og afprøvet i HPA-programmet ${ }^{13}$. Dataindsamlingen startede i marts 2011 med indsamling af baseline-informationer, en screening af alle børn, ved at pædagoger udfyldte screeningsskemaer om børnenes socioemotionelle kompetencer målt på Strengths and Difficulties Questionnaire (SDQ) og kognitive kompetencer inspireret af internationale skalaer og siden anvendt i HPA-projektet (Jensen et al., 2009) til at måle børns læring fra tidligste alder. I marts 2012 blev der gennemf $\varnothing$ rt midtvejsscreeninger, mens den afsluttende dataindsamling fandt sted i marts 2013.

Projektet adskiller sig fra tidligere forskning om effekter af en tidlig indsats i dagtilbud på tre afgфrende måder. For det første ved at interventionen retter sig imod både at styrke det enkelte barns kompetencer, socioemotionelt og kognitivt, og ved at udvikle inkluderende læringsmiljøer som en del af indsatsen. For det andet ved at belyse effekter gennem et randomiseret, kontrolleret eksperiment, der til forskel fra de tidligere internationale studier, bl.a. 'Perry Preschool'-projektet, baserer udvælgelsen på institutionsniveau frem for på individniveau. Endelig for det tredje er VIDA-forskningsprogrammet tilrettelagt som en indsats i almentilbuddet i danske daginstitutioner, der derved retter sig mod alle danske børn (97\% af alle 3-5-årige børn deltager i dagtilbud) ${ }^{14}$ (Danmarks Statistik 2010). Der er altså i VIDA ikke udtaget specifikke børn til en særlig 'specialpædagogisk indsats' eller udvalgt særlige 'ildsjæle' blandt pædagogerne til at gennemføre interventionen.

I unders $\varnothing$ gelsen af effekter har vi analyseret resultaterne af VIDA-programmet på børns socioemotionelle kompetenceudvikling på fem dimensioner, som SDQskalaen lægger op til, samt den kognitive udvikling på udvalgte indeks, som den anvendte læringsmålsskala lægger op til. Desuden har vi unders $\emptyset$ gt sammenhænge mellem social baggrund og børns kompetenceniveau i udgangspunktet som en slags forudsætninger for unders $\varnothing$ gelsen (baseline). Vi har endvidere taget højde for social baggrund via vores metode ${ }^{15}$.

Den meget korte version af resultaterne af unders $\varnothing$ gelsen kan opdeles i fire overordnede punkter: 1) Positiv effekt på det overordnede plan, 2) ikke st $\varnothing r r e ~ e f f e k t e r$ for de mest udsatte børn end for de andre børn, etnicitet dog undtaget, 3) for-

13 For nærmere beskrivelse af design og mere konkret af segmentering af daginstitutioner i forhold til andel af 'udsatte børn' i projektet henvises til Jensen et al. (2011). VIDA-statusrapport 1, kapitel 4.1 og 4.2 samt samme rapports Bilag 6.

14 Danmarks Statistik, if $\varnothing$ lge Fremtidens Dagtilbud (2012).

15 For en grundig gennemgang af effektanalysen henvises til Jensen, B., Jensen, P. \& Rasmussen, A. W. (2013). VIDA-forskningsrapport 1. Effekter af VIDA. I: VIDA-forskningsserien 2013:01. 
skelle mellem det socioemotionelle og det kognitive udbytte og 4) institutionsforskelle. De fire punkteruddybes efterf $\varnothing$ lgende.

\section{VIDA - En innovativ tilgang til tidlig indsats}

Den form for det, vi kan kalde en fornyende (innovativ) tilgang til tidlige indsatser i dagtilbud, som VIDA repræsenterer, er karakteriseret ved at tage udgangspunkt i den konkrete og aktuelle politiske situation og kontekst. Dvs. en traditionel skandinavisk idé om at arbejde ud fra et bottom-up-perspektiv og lade idéerne blomstre fra praksis kombineres med en idé om at skabe intervention ud fra et top-down-perspektiv, som indebærer, at praksis inviteres til at deltage i en uddannelse, som bl.a. uddanner deltagerne i at anvende på forhånd definerede vidensgrundlag, materialer og værkt $\varnothing$ jer.

\subsection{OVERORDNEDE FUND}

\section{Socio-emotionelle kompetencer og trivsel}

Resultaterne af de statistiske analyse viser overordnet, at VIDA- interventionen har haft positive effekter på flere SDQ-dimensioner. Effekten er målt, efter at den fulde interventionsperiode er afsluttet i 2013. Resultaterne viser for det første, at VIDA-Basis-interventionen signifikant forbedrer to af de fem SDO-dimensioner: ved at børns emotionelle problemer og adfærdsproblemer reduceres. De tre $\varnothing \mathrm{v}$ rige dimensioner er også forbedrede, ved at hyperaktivitet og kammeratskabsproblemer er reduceret og prosocial adfærd fremmet, sk $\varnothing$ nt effekterne ikke er signifikante på et konventionelt niveau. Det skal endvidere understreges, at den totale SDQ-score (som repræsenterer summen af de første fire dimensioner) også er signifikant forbedret for VIDA-Basis-interventionen. For børn i institutioner, der har deltaget i VIDA-Basis-interventionen, er emotionelle problemer reduceret med 0,47 på SDQ-skalaen, og adfærdsproblemer er reduceret med 0,56, hvilket er det samme som ca. en fjerdedel af standardafvigelsen for begge udfald, dvs. effektst $\varnothing$ rrelserne er omkring 0,25.

Resultaterne viser for det andet, at VIDA-Basis +-interventionen også har haft positive effekter, men det er dog kun en ud af de fem SDQ-dimensioner, der er signifikant forbedret, nemlig børns adfærdsproblemer, som er reduceret. Generelt er effekterne af VIDA-Basis +-interventionen mindre end de tilsvarende effekter af VIDA-Basis.

Ud over de ovennævnte SDQ-dimensioner og den totale score er der også benyttet et særskilt supplement til SDQ-spørgsmålene, hvor pædagogerne har svaret 
på, om de samlet set vurderer, at barnet har vanskeligheder på de sociale og personlige områder, som indgår i SDQ-spørgsmålene. På baggrund af disse svar er der beregnet et vanskelighedsindeks ('SDO impact score'). Vi har også analyseret effekten af VIDA-Basis- og VIDA-Basis +-interventionerne på dette vanskelighedsindeks. Resultaterne af denne analyse bekræfter de overordnede effekter, som er fundet ovenfor. Det ses således, at VIDA-Basis-interventionen signifikant reducerer de samlede vanskeligheder, mens VIDA-Basis +-interventionen også reducerer de samlede vanskeligheder, men denne effekt er dog kun signifikant på et $10 \%$ signifikansniveau.

Vores overordnede resultater viser som nævnt positive effekter, ved at flere dimensioner af SDQ er forbedret ved interventionen. Disse overordnede effekter afspejler gennemsnitlige effekter for interventionsgruppen set som helhed, og derfor er det interessant også at unders $\emptyset$ ge forskelle i effekter mellem forskellige undergrupper.

\section{Forskelle}

Vi er specielt interesserede i at unders $\varnothing$ ge, om interventionen har st $\varnothing$ rre effekt for socialt udsatte børn end for andre børn. Derfor går vi videre og analyserer også modeller, hvor vi tillader effekterne at variere på tværs af undergrupper.

Mange af disse udvidede specifikationer viser ikke nogen signifikante forskelle i effekter på tværs af undergrupper. Generelt finder vi, at effekten af VIDAinterventionen (både VIDA-Basis og VIDA-Basis +) er den samme for piger og drenge, for børn af højtuddannede mødre og lavtuddannede mødre, for børn i lavindkomst familier og andre familier, og for børn af dansk oprindelse og børn med anden etnisk baggrund end dansk. Det er således primært for opdelingen på basis af familiestatus, at vi finder signifikante forskelle i effekter. Der er imidlertid en række interessante forskelle, som er værd at lægge mærke til, i nogle af de udvidede specifikationer for enkelte af dimensionerne.

Moders uddannelse. Vi skelner mellem mødre med mindre end 12 års uddannelse (lavt-uddannede) og med mindst 12 års uddannelse (højtuddannede). Det er bemærkelsesværdigt, at de (insignifikante) effekter af VIDA-Basis på hyperaktivitet, problemer med kammeratskabsrelationer og prosocial adfærd kun ses blandt børn med højtuddannede mødre, mens der ikke er nogen effekt for disse dimensioner for børn af lavtuddannede mødre. Som en konsekvens af dette resultat er effekten af VIDA-Basis på den totale SDO-score ikke signifikant for børn af lavtuddannede mødre, men kun for børn af højtuddannede mødre. 
Familieindkomst. For børn fra familier med en meget lav indkomst (under f $\varnothing \mathrm{r}-$ ste decil af indkomstfordelingen) er det generelle billede, at for disse børn giver VIDA-Basis en mindre forbedring i deres SDQ-scores på alle dimensioner (bortset fra kammeratskabsproblemer) end for børn af andre familier. Dog er det kun for adfærdsproblemer, at der er signifikant forskel på effekterne for børn fra lavindkomstfamilier og andre børn (og kun på $10 \%$ signifikansniveau), mens de $\emptyset$ vrige effekter ikke er signifikant forskellige. For VIDA-Basis+ observeres det modsatte billede, således at børn fra lavindkomstfamilier opnår en større forbedring end andre børn for alle dimensioner, men dog kun med en signifikant forskel for kammeratskabsproblemer.

Etnicitet. Mest bemærkelsesværdigt er det, at effekten af VIDA-Basis på kammeratskabsrelationer nu er signifikant forskellig fra 0 på et $5 \%$ signifikansniveau for børn af ikke-dansk etnisk oprindelse, og den er også signifikant forskellig fra effekten for danske børn. VIDA-Basis-interventionen har således formået at forbedre kammeratskabsrelationer for børn med anden etnisk baggrund end dansk, mens den ikke har effekter på danske børn for denne dimension.

Familiestatus. Som et mål for familiestatus har vi benyttet en indikatorvariabel for, om barnet bor hos en enlig forælder. For denne specifikation finder vi, at VIDA-Basis giver signifikant mindre forbedringer vedrørende både emotionelle problemer og adfærdsproblemer for børn, som bor hos en enlig forælder. Delvist som konsekvens af dette finder vi også en signifikant mindre forbedring i den totale SDO-score for disse børn. Tilsvarende finder vi, at VIDA-Basis + har en signifikant mindre forbedring på hyperaktivitet for børn, som bor hos en enlig forælder.

Sammenfattende viser analysen af forskelle, at det ikke generelt har været muligt for hverken VIDA-Basis eller VIDA-Basis + at kunne påvise st $\varnothing$ rre forbedringer for socialt udsatte $b \phi r n$ end for andre $b \phi r n$. Der er dog enkelte undtagelser fra dette generelle billede: VIDA-Basis har været i stand til signifikant at forbedre kammeratskabsproblemer for børn med ikke-dansk etnisk baggrund, mens VIDA Basis + har været i stand til signifikant at forbedre kammeratskabsproblemer for børn fra lavindkomstfamilier.

Konklusionen af analyserne på de to delperioder (fra 2011-2012 og 2012-2013) er, at den fulde effekt af interventionerne ikke kan genfindes i de to delperioder, men at det kræver analyser på den samlede analyseperiode for at påvise signifikante effekter af VIDA-Basis og VIDA- Basis +. 
Da interventionen har fundet sted på institutionsniveau, vil det endvidere være specielt være relevant at inddrage institutionsspecifikke oplysninger i analysen. Vi har således foretaget analyser af mulige forskelle på effekterne mellem kommunerne og mellem institutioner med henholdsvis få og mange socialt udsatte børn. Disse analyser er foretaget på samme måde som analyserne af de heterogene effekter i forrige afsnit.

Når der ses på forskelle i effekterne mellem kommunerne, så er hovedresultatet, at for VIDA-Basis + findes der ingen signifikante forskelle, mens der for VIDA-Basis findes nogle få signifikante forskelle. Der er således en enkelt kommune, som har opnået en signifikant forbedring i den prosociale adfærd, og der er ligeledes en enkelt anden kommune, som har opnået en signifikant forbedring i kammeratskabsproblemer. Begge disse resultater skal ses i lyset af, at de overordnede effekter for disse to dimensioner ikke er signifikante.

Vi har opdelt institutionerne i to grupper baseret på den udvælgelse, som blev foretaget ved projektets start (se en mere detaljeret beskrivelse af dette i VIDAstatusrapport 1). Her blev institutionerne inddelt efter deres andel af socialt udsatte børn, og denne inddeling er her benyttet til at definere institutioner med mange socialt udsatte børn som institutioner, hvor denne andel er $40 \%$ og derover, og institutioner med få udsatte børn som institutioner, hvor denne andel er under $40 \%$.

Blandt de børn, som indgår i analysen, er der 15 \%, som går i institutioner med mange udsatte børn. Den eneste dimension, hvor vi finder signifikante forskelle mellem de to typer institutioner, er emotionelle problemer. Disse signifikante forskelle findes både for VIDA-Basis og for VIDA-Basis +, dog med modsat fortegn. Vi finder således, at VIDA-Basis-interventionen ikke medfører nogen signifikant forbedring i institutioner med mange udsatte børn (i modsætning til det overordnede resultat, hvor VIDA-Basis-interventionen signifikant forbedrer denne SDOdimension). Omvendt finder vi, at VIDA-Basis +-interventionen fører til en signifikant forbedring for institutionerne med mange udsatte børn (i modsætning til det overordnede resultat, hvor VIDA-Basis +-interventionen ikke medf $\varnothing$ rer nogen signifikant ændring i denne SDQ-dimension).

\section{Læring}

I lighed med analyserne af effekter mål på børns socio-emotionelle udvikling er også unders $\varnothing$ gt effekterne af VIDA-Basis- og VIDA-Basis+-interventionerne på en række kognitive lærings mål. Resultaterne af analysen af effekterne er for de fire 
kognitive mål, som vedrører børnenes læringskompetencer, og for tre kognitive mål, som vedrører børnenes læringsberedskaber. Det overordnede billede er, at der hverken for VIDA-Basis- eller VIDA-Basis +-interventionen kan påvises nogen signifikant effekt på de kognitive mål. Det eneste mål, hvor der findes en svagt signifikant effekt (på 10 \% signifikansniveau), er matematisk kompetence.

Generelt ses det, at børnenes læringskompetencer bliver mærkbart forbedrede over tid, hvilket naturligvis afspejler, at børnene bliver ældre, og at de målte kompetencer i meget h $\varnothing$ j grad udvikles i takt med børnenes alder, men ikke som f $\varnothing$ lge af VIDA.

\subsection{SAMMENFATNING}

VIDA har en effekt på alle børn - ift. trivsel og socio-emotionel udvikling, (ikke kognitive læring), men det er ikke sådan, at programmet i særlig grad løfter de udsatte børn.

De igangsatte forandringsprocesser har givet positive effekter på flere områder af alle børns social-emotionelle udvikling og trivsel. Der er derudover en særskilt positiv effekt af VIDA-Basis for børn af anden etnisk baggrund, idet kammeratskabsproblemer for disses børns vedkommende er mindsket signifikant gennem indsatsen, en effekt der ikke kan konstateres blandt de etnisk danske børn. Der er tilsvarende en særkilt positiv effekt af VIDA-Basis+ for b $\varnothing$ rn fra lavindkomstfamilier, idet kammeratskabsproblemer for disse børn er mindsket signifikant gennem indsatsen. Endvidere har det vist sig, at VIDA-Basis+-forældremodelprogram har haft positiv effekt på en ud af de fem dimensioner på socio-emotionelle udvikling, der er unders $\varnothing g t$, hvor forældreinvolvering har vist sig at have signifikant effekt i reducering af adfærdsproblemer hos involverede børn. Overraskende har der ikke vist sig de forventede effekter på børnenes kognitive læring, ligesom der heller ikke er fundet særlige effekter af modelprogrammerne, hvad angår de mest udsatte børn.

Det forhold, at der ikke som forventet er opnået effekt for så vidt angår børnenes kognitive læring og en særlig effekt ift. de mest udsatte børn kan have flere forklaringer. Én af dem kan være den forholdsvis korte indsatsperiode på 2 år. Studiet har påvist, at der kan opnås korttidseffekter af en toårig intervention som VIDA. Flere førende forskere understreger betydningen og relevansen af longitudinelle børnestudier, der undersøger langtidseffekter af det at gå i dagtilbud. Sådanne unders $\varnothing$ gelser ville kunne vise, om VIDA-modelprogrammet vil kunne opnå langtidseffekter. 
Resultaterne giver endvidere anledning til at gå videre med at unders $\emptyset$ ge mere uddybende, hvordan effekter påvirkes af institutionernes forudsætninger. Dels ved at se nærmere på vilkår og implementeringsbetingelser og dels ved at se nærmere på sammenhænge mellem leder- og pædagogkompetencer og effekter. En tidligere unders $\varnothing$ gelse (Kan daginstitutioner g $\varnothing \mathrm{r}$ en forskel, Jensen, 2005) pegede på, at der tales meget om at fremme børns ressourcer, men når det kommer til de udsatte børn, er det stadig deres fejl, mangler og uhensigtsmæssige adfærd, der sigtes imod. Vi ser gennem casestudiet om "Organisatorisk læring i VIDA", at sådanne tendenser er under forandring. Casestudiet om "Forældreinddragelse i VIDA" viser eksempler på positive forandringer som følge af VIDA, men vi ser også eksempler på, at det kan være vanskeligt at arbejde ressourceorienteret - når det gælder forældreinddragelse. Sådanne fund giver anledning til at unders $\varnothing$ ge disse forhold nærmere og medinddrage dem i videregående analyser af faktorer af betydning for effekt.

Efterfølgende skal vi se på virkninger af den organisatoriske læring og nye former for forældreinddragelse, der er unders $\varnothing$ gt gennem casestudier af dagtilbuds deltagelse i VIDA-programmerne. 


\section{KONKRETE FORANDRINGER I PRAKSIS SOM FØLGE AF VIDA - CASESTUDIER}

\subsection{ANALYSE AF FORANDRINGER BASERET PÅ CASESTUDIER AF ORGANISATORISK LAERING ${ }^{16}$}

I dette kapitel belyser vi casestudiets overordnede forskningsspørgsmål: Hvordan realiserer de udvalgte og unders $\varnothing$ gte VIDA-dagtilbud VIDA-interventionerne i praksis, og hvilke faktorer fremmer og hæmmer denne udviklingsproces ud fra et perspektiv om organisatorisk læring? Analysen baseres på data fra en surveyunders $\varnothing$ gelse suppleret med interview med alle ledere - begge gennemf $\varnothing \mathrm{rt}$ $i$ baseline og endline.

VIDA-programmet retter sig overordnet mod at uddanne ledere og pædagoger til at arbejde vidensbaseret, målrettet og systematisk med at styrke børns trivsel og læring gennem inklusion - og dette baseret på de tre perspektiver: ressourcesyn, aktiv læring og organisatorisk læring.

Casestudiet bidrager med viden om professionelles læreprocesser og den relation, der viser sig mellem uddannelse, implementering af ny viden og ny pædagogisk praksis. Denne proces formodes at påvirke effekterne på børneniveau. Casestudiet unders $\emptyset$ ger hypotesen om, at deltagelse i VIDA-uddannelsen ændrer dagtilbuddenes pædagogiske praksisser, så der på den måde skabes nye og forbedrede 
rutiner for børnene, som igen skaber grundlag for, at børn i VIDA-dagtilbud får nye muligheder for trivsel, læring og udvikling gennem inklusion.

\section{Daginstitutionernes arbejde med forandringer af pædagogisk praksis}

Analysen, der præsenteres her, sætter fokus på hvilke forandringer, der er sket fra baseline til endline. Unders $\varnothing$ gelsen ser både på institutionernes forandringer baseret på 1) det at arbejde vidensbaseret, målrettet og systematisk med forandringer som følge af VIDA, 2) lederes arbejde med at skabe ledelsesformer, der fremmer organisatorisk læring og en læringsorienteret arbejdspladskultur, og 3) den motivation for arbejdet der kan spores i de deltagende institutioner, og som opfattes som afgørende forudsætninger for, at egentlige forandringer implementeres.

Sammenfatningen af denne analyse falder i to dele. Første del baserer sig på fund fra survey-unders $\varnothing$ gelsen for alle ledere og medarbejdere, der har deltaget i VIDA-uddannelsen, og derved kan vi pege på nogle generelle og mere overordnede fund. Anden del uddyber surveyfundene ved at inddrage nogle udvalgte fund fra analysen af kvalitative data.

\section{Om at arbejde teori- og vidensbaseret, målrettet og systematisk - en organisa- torisk lærings- og forandringsproces}

St $\varnothing$ rsteparten af deltagerne i VIDA-surveyunders $\emptyset$ gelsen 2013 (64 \%) svarer, at de arbejder ud fra bestemte pædagogiske teorier generelt, hvilket er en forbedring i forhold til baseline-målingen, hvor 59 \% svarede ja. Forskellen er signifikant. Endnu mere markant er stigningen, hvad angår deltagernes anvendelse af pædagogiske teorier i forhold til udsatte børn, idet 43 \% af alle deltagere i 2011 rapporterede, at de arbejdede med en pædagogisk teori, mens denne andel ved 2013-analysen er steget til 59 \%. Der er således sket en markant, højsignifikant stigning vedrørende det at arbejde målrettet med pædagogisk teori, når det gælder indsatsen over for socialt udsatte børn i dagtilbuddene. Tallene vidner om, at der er sket en positiv forandringsproces gennem VIDA på dette område, omend vi kan konstatere, at der stadig er et stykke vej hen imod at få alle med på at arbejde teoribaseret, idet den andel af informanter, der har deltaget i VIDA-uddannelsen og stadig ikke arbejder teoretisk i forhold til udsatte børn, er $41 \%$.

I forhold til det at arbejde systematisk og målrettet med indsatser over for udsatte børn ser vi en endnu tydeligere stigning, idet st $\varnothing$ rsteparten, nemlig $79 \%$, i høj grad eller meget høj grad arbejder systematisk og målrettet med indsatser over for socialt udsatte børn mod en andel på 59 \% ved baseline, og også denne stigning er højsignifikant. 
Vi ved endvidere fra vores studier i praksis og kontakt med konsulentnetværk, at VIDA har gjort en forskel ved, at dagtilbuddenes arbejde gennem det toårige projektforl $\varnothing \mathrm{b}$ er blevet klart mere vidensbaseret, målrettet og systematisk.

Senere i kapitlet vender vi tilbage til dette og viser, hvordan denne forandring konkret folder sig ud i praksis, når dagtilbuddene arbejder teoribaseret i pædagogisk praksis og er blevet bedre til at organisere sig, så systematik og målrettethed bliver en del af hverdagens praksisser. Fx er det at organisere pædagogiske aktiviteter omkring små grupper af børn helt klart en effekt af arbejdet med VIDA, idet analyser og evaluering i dagligdagen har vist, at dette giver bedre udbytte for det enkelte barn.

Ifølge ledere og kommunernes konsulenter er der således opnået en større bevidstgørelse blandt medarbejderne om betydningen af og gevinsten ved at arbejde systematisk og målrettet. Casestudiet viser også, at lederens rolle og opgave er afgørende i den forbindelse, og at denne rolle og opgave er ændret betydeligt som følge af de udfordringer, der ligger i at arbejde så målrettet og systematisk, som VIDA fordrer.

\section{Ledelse af organisatorisk læring}

Vi har også set på ledernes rolle og opgave i surveyunders $\varnothing$ gelsen. Lederne lægger stor vægt på demokratiske ledelsesformer, inddragelse, anerkendelse og dialog. De fleste er enige i, at der er gode betingelser for læring i organisationen. Der er dog påvist en række signifikante forskelle mellem lederes og pædagogiske medarbejderes opfattelser af forudsætninger for, om der eksisterer eller skabes en læringskultur i dagtilbuddet.

I takt med at flere af dagtilbuddene arbejder teoribaseret, målrettet og systematisk i 2013, har det vist sig, at det, vi så var svært eller næsten for udfordrende at realisere for lederne i 2011 mht. at sætte læring i gang i det samlede dagtilbud, er ændret markant. Surveyunders $\varnothing$ gelsen viser bl.a. i vores valg af indikatorer på organisatorisk læring, at holdninger til og oplevelse af læringssituationen i dagtilbuddene er ændret på meget afgфrende vis. Vi har bl.a. undersøgt en antagelse om, at en opmuntrende og eksperimenterende kultur, risikovillighed, inddragelse af medarbejdere i beslutninger, fri kommunikation i organisationen og interaktion med omgivelserne er vigtige faktorer, som påvirker organisatorisk læring. 
Vi finder ved afslutningen af projektet markante og højsignifikante forskelle fra baseline (2011) på en række af de spørgsmål, som er indeholdt i surveyen, som fx:

- At modtage støtte og blive opmuntret, når man præsenterer nye idéer og viden (stigning fra $85 \%$ (2011) til $96 \%$ (2013)),

- At nye initiativer bliver mødt med en positiv respons, så man føler sig opmuntret til at udvikle nye idéer (fra 83 \% i 2011 til 92 \% i 2013),

- $\quad$ At blive opmuntret til at handle på nye måder (fra 84 \% i 2011 til 93 \% i 2013)

- At man i mit dagtilbud vover sig ud i ukendte områder (fx at bruge ny viden og metoder). (her er forandringen endnu mere markant fra $64 \%$ i 2011 til $83 \%$ i 2013).

Disse eksempler og flere til vidner om, at der er sket forandringer vedrørende organisatorisk læring, som også drejer sig om forbedringer af oplevelsen af handlemuligheder.

De signifikante ændringer, vi har set fra 2011 til 2013, antages at være udtryk for en holdningsudvikling, der angiver nye forudsætninger for arbejdet med organisatorisk læring i de unders $\varnothing$ gte dagtilbud og dermed nye forudsætninger for at højne kvaliteten i det daglige pædagogiske arbejde.

\section{Store virkninger - vidensbasering omsat i positiv motivation og forventninger}

Vi har ovenfor set, at dagtilbuddene har rykket sig, både hvad angår det at arbejde vidensbaseret, målrettet og systematisk, og hvad angår det at have en overordnet positiv holdning til at have nye handlemuligheder og opleve at kunne arbejde i en organisatorisk læringskultur. Hvordan ser det ud med forventninger til og motivation for VIDA-projektet efter to års projektforl $\varnothing b$ ?

Denne tredje faktor, motivation og forventninger til VIDA's betydning, er unders $\varnothing$ gt ved at sp $\phi$ rge til forventninger om, hvorvidt deltagelse i VIDA vil kunne gøre en forskel for udsatte børn her og nu, på langt sigt (ind i skolen) og på længere sigt (videre frem i livet). Dertil har vi spurgt direkte til deltagernes motivation for at deltage i VIDA.

Analysen af 2013-data viser, at der er sket en positiv udvikling fra 2011 til 2013 med hensyn til at tro på, at VIDA vil gøre en forskel her og nu og på længere sigt. Forskellen fra 2011 til 2013 er høj-signifikant. Hvad sådanne forventninger betyder, kommer vi nærmere ind på i den kvalitative analyse, men det antages ifølge VIDA's bagvedliggende teorigrundlag, at sådanne høje, positive forventninger spiller ind på implementeringsgraden af programmet. 


\section{Åben læringskultur}

Når vi læser os mere ind de kvalitative interview, får vi indsigt i, hvad der kendetegner denne ændring. Her finder vi, at der er sket en tydeligg $\varnothing$ relse og eksplicitering af, at der nu arbejdes målrettet og systematisk med at integrere teoretisk og forskningsbaseret viden, som deltagerne har tilegnet sig på VIDA-uddannelsen og lært at arbejde med i praksis. Hovedparten af de deltagende dagtilbud arbejder med at skabe en åben læringskultur, der er kendetegnet ved kritisk refleksion over eksisterende handlinger kombineret med fors $\varnothing \mathrm{g}$ på at ændre forskellige typer af pædagogiske praksisser med afsæt i ny, tilegnet viden.

Det karakteristiske ved at følge VIDA-programmets oplæg til at arbejde med en pædagogisk praksis, der er baseret på viden, en eksperimenterende tilgang og læring, er, at de involverede dagtilbud oplever, at de gennem VIDA-programmet får redskaber og værkt $\varnothing j e r$, der $g \varnothing r$ dem i stand til at bevæge sig væk fra rutinebaserede handlingsm $\varnothing$ nstre og skabe forandringer, og at dette sker gennem en åben læringskultur, der $s \varnothing$ ger at bringe alle medarbejdere i spil ${ }^{17}$. Den nye, pædagogiske praksis åbner således op for, som lederne beskriver det, at de og de ansatte t $\varnothing \mathrm{r}$ og kan tænke nye pædagogiske løsninger på eksisterende udfordringer i hverdagen gennem afprøvning af nye aktiviteter og organiseringer - her forstået som aktive læringsprocesser, som de selv igangsætter.

På samme vis indikerer endline-analysen endvidere, at denne vidensorienterede praksis er gældende for hele dagtilbuddet, hvor det særegne bliver, at de deltagende dagtilbud giver udtryk for, at de efter deltagelsen har udviklet kapacitet til at udvikle og afprøve konkrete, nye praksisser. I VIDA-programmets terminologi ville vi sige, at dette fund udtrykker, at deltagerne udvikler nye handlekompetencer.

Deltagelse i VIDA-projektet har ifølge lederne betydet, at den pædagogiske praksis ikke mere handler om at følge de gamle rutiner og vaner, men at der i stedet gennem VIDA-projektets redskaber og værktøjer er åbnet op for at se udfordringer i forhold til udsatte $b \phi r n$ fra andre og helt nye perspektiver, der $\varnothing$ ger handlingsmulighederne i dagtilbuddene.

Skiftet fra en pædagogisk praksis kendetegnet af erfaringer og rutiner til en pædagogisk praksis præget af en vidensbaseret, eksperimenterende og læringsorienteret tilgang til det pædagogiske arbejde er dermed tydeligt. Hovedparten af 
de interviewede ledere omtaler således forskellige typer af eksperimenter, der alle drejer sig om, at man nu arbejder eksplicit med læring og udvikling af de pædagogiske praksisser i dagtilbuddet, hvilket ikke var sædvane, før VIDA-projektet blev igangsat.

\section{Betydning af faglig viden}

I forhold til spørgsmålet om betydningen af faglig viden, understreger endlineanalysen vigtigheden af at arbejde vidensbaseret i de pædagogiske praksisser. Vi ser en tydelig bevægelse væk fra det, informanterne kalder "syn's'ninger" til "vidensbaserede handlinger". Resultatet af analysen af 2013-data viser med tydelighed for en stor del af ledernes vedkommende, at de nu på baggrund af deltagelse i VIDA-projektet anser det som betydningsfuldt, at de pædagogiske praksisser baserer sig på viden frem for på erfaringer og vaner.

Som denne leder udtrykker det: "faglig viden skal være på plads hos pædagogerne for at kunne overhovedet gå ud at se, hvad det er, de skal gøre, for ellers bliver det bare sådan nogle syn"sninger og hver enkelts udgangspunkt i livet, og hvad man lige har med sig og det... er min opgave som ledelse at sørge for, at der er den viden i huset, der skal være for at kunne varetage de opgaver" (Æ-P4-233).

Dette citat underbygger pointen om, at hvis forandringer skal realiseres, så kræver det dels faglig viden blandt pædagogerne, og dels at ledelsen tager opgaven på sig mht. at tage ansvar for, at der skiftes fra en erfaringsbaseret praksis til en videns- og teoribaseret pædagogisk praksis. Dette bliver tæt sammenkoblet med at tage et nyt ledelsesansvar, så der opstår en samlet måde at løse pædagogiske problemstillinger på i hverdagen. Hermed ser vi en strategisk, ledelsesorienteret tilgang til håndteringen af at implementere en vidensbaseret, systematisk og målrettet ny indsats i dagtilbud, som den VIDA-programmet lægger op til.

Et aspekt af dette skift er, at deltagerne udtrykker, at de $t \varnothing r$ og kan gennemf $\varnothing$ re læreprocesser, som vi så det antydet ovenfor under analysen af organisatorisk læring. Et andet og lige så vigtigt aspekt er, at de organisatoriske læreprocesser i hovedparten af dagtilbuddene nu foregår systematisk og målrettet. Hermed ser vi i analysen en karakteristisk, tydeligere ledelse stå frem i de unders $\varnothing$ gte dagtilbud. Denne ledelse arbejder på en strategisk måde med at tilpasse ressourcer i dagtilbuddet, fx arbejdsdeling, strukturer og regler, viden og kompetencer, til de opgaver og udfordringer, de konfronteres med i forhold til at optimere trivsel og læring for gruppen af udsatte børn. 
En af årsagerne til det st $\varnothing$ rre fokus på at arbejde mere målrettet med reorganiseringer og strukturer er, at lederne i perioden med VIDA-projektet har erfaret, at et mere målrettet og systematisk fokus har haft positive effekter for kvalitet og effektivitet i de konkrete pædagogiske praksisser. Princippet om at strukturere hverdagen på en ny måde knytter sig til en фget bevidsthed om betydningen af, hvordan man sætter børnegruppen sammen, og hvilke personer fra personalegruppen der passer bedst ind i opgaven med netop deres viden og kompetencer. Det at lederen oplever, at denne arbejdsmåde har en positiv virkning, styrker yderligere bestræbelserne på at udvikle og fastholde udviklingsprocesser som følge af VIDA.

Endelig har vi også set "status quo" i forhold til den pædagogiske praksis, men kun i ganske få tilfælde. For denne lille gruppe drejer det primære udsagn sig om, at deltagelse i VIDA ikke har fået dem til at ændre fokus i forhold til arbejdet med udsatte børn. To årsager til dette fænomen bliver fremhævet: For det første at VIDA-metoder og -viden (blot) var noget, de på forhånd arbejdede med i institutionen. For det andet at årsagen til status quo er fravær af ledelse en stor del af projektperioden. Dette sidstnævnte vilkår, at der mangler en leder, er tydeligvis en hæmmende faktor for implementering af en st $\varnothing$ rre, målrettet satsning som VIDA-modelprogrammet. Dette understreger igen analysens $\emptyset$ vrige fund om betydningen af lederen, der træder i karakter og leder sådanne læreprocesser, som VIDA indebærer.

Konklusionen på denne del af analysen er, at deltagerinstitutionerne har forandret sig markant fra baseline til endline på de fleste parametre for at arbejde vidensbaseret, målrettet og systematisk. Et af redskaberne er en tydelig lederrolle, som faciliterer organisatorisk læring, og nogle af indikatorerne på succes er motivation og positive forventninger til programmets betydning nu og fremover.

I det følgende ser vi på forandringsprocesser baseret på casestudier i VIDA-Basis +-forældre-institutioner.

\subsection{KONKRETE INDSATSER RETTET IMOD NYE FORMER FOR FOR/ELDREINDDRAGELSE ${ }^{18}$}

VIDA-Basis +-programmet retter sig overordnet mod at uddanne ledere og pædagoger til at medinddrage forældre i forhold til at forbedre børns læring og trivsel. 
Målet er at kvalificere forældresamarbejdet i dagtilbuddet, både generelt og i forhold til udsatte familier.

Casestudiet om VIDA-Basis +-programmets virkninger baseres som det forrige casestudie på analyser af data fra en survey- og en interviewunders $\emptyset$ gelse med alle ledere gennemf $\phi$ rt i baseline og endline.

Her skal de vigtigste fund fra VIDA-Basis +-casestudiet præsenteres med fokus på, hvordan VIDA-Basis +-programmet har haft indflydelse på den måde, dagtilbuddene inddrager forældre på i deres pædagogiske arbejde. Resultaterne er primært baseret på en kvalitativ dataindsamling (endline), samt resultater fra surveymålinger 2011-2013. Vi belyser på den baggrund følgende to forskningsspørgsmål:

1. Hvordan realiserer institutionerne interventionernes formål, og hvad i denne proces fremmer og hæmmer forældreinddragelse?

2. Hvordan medvirker interventionerne til, at udsatte børns forældre konkret ændrer adfærd i relation til deres børn og i relation til samarbejdet med dagtilbuddet om at stimulere deres børns trivsel og læring?

\section{Daginstitutioners arbejde med forældreinvolvering i VIDA-Basis +}

Fire underspørgsmål viser sig i den forbindelse: Hvilken virkning har institutionernes deltagelse i VIDA-programmet på deres forældresamarbejde? Hvordan arbejdes der i dagtilbuddene med VIDA-Basis +-interventionen? Hvordan f $\varnothing$ rer interventionen til udvikling - set fra institutionens perspektiv? Hvordan opleves interventionen af forældrene?

Det primære fokus for casestudiet er at afdække konkrete forandringsprocesser i dagtilbuddenes tilgang til og tilrettelæggelse af forældresamarbejde og forældreinddragelse samt forældres ændrede adfærd i relation dels til eget barn og dels til deres deltagelse i institutionen både i hverdagen og i forældrearrangementer.

\section{Virkning af institutionernes deltagelse i VIDA-programmet på forældresamarbejdet}

De statistiske analyser af surveydata viser få, signifikante forskelle mellem baseline- og endline-måling. Analyserne viser dog, at der i perioden 2011-13 er sket nogle forandringer i forhold til hvilke typer af forældrearrangementer, der prioriteres i dagtilbuddene. VIDA-institutionerne afholder i mindre grad end tidligere arbejdsdage og caféeftermiddage. Sammenholdt med de kvalitative analyser kan der peges på en mulig sammenhæng med, at dagtilbuddene i højere grad har fo- 
kus på at kombinere forskellige formål omkring forældreinddragelse - og at forældrenes aktive bidrag tænkes på andre måder end som deciderede arbejdsdage.

VIDA-Basis +-dagtilbuddene prioriterer det at skabe kontakt mellem forældrene indbyrdes højere efter deltagelsen i VIDA-programmet. Det er dog bemærkelsesværdigt, at kontrolgruppen prioriterer dette højere end VIDA-dagtilbuddene. VIDA-Basis +-institutionerne ligger signifikant over de $\varnothing$ vrige institutionstyper med hensyn til deres vurdering af, hvor meget VIDA-programmet fortsat vil påvirke den pædagogiske praksis inden for forældresamarbejdet.

Samlet kan vi altså konkludere, at der kun kan måles mindre effekter af VIDABasis +-institutionernes deltagelse i VIDA-programmet i forhold til deres måde at tilrettelægge og værdisætte deres forældresamarbejde på. Dog er der basis for på baggrund af det samlede materiale at konkludere, at VIDA-Basis +-institutionerne har igangsat udviklingsprocesser omkring deres forældresamarbejde og forældreinddragelse - og at VIDA-programmet på den måde har haft betydning i de deltagende institutioner.

\section{Interventionens bidrag til udvikling af forældresamarbejdet}

VIDA-Basis +-dagtilbuddene har deltaget aktivt i forskellige eksperimenter omkring deres forældresamarbejde. Det har givet anledning til dels 1) at revurdere og gentænke deres forældrearrangementer både i indhold og form. Der arbejdes med mere dynamiske arrangementer med aktiviteter, dialog og interaktion, som er struktureret og underst $\varnothing$ ttet af personalet. Der ses en opmærksomhed på at arbejde med forskellige typer af arrangementer og dermed forskellige muligheder for forældre for at deltage og bidrage. Dels 2) at revurdere forståelser af familierne og 'hvad der skal til' for, at forældrene deltager. Der tænkes således i at være mere direkte ops $\varnothing$ gende og inviterende over for forældre, som ikke plejer at deltage.

Den kvalitative analyse viser samlet set, at der i dagtilbuddene arbejdes mere systematisk med at inddrage forældre og indtænke forældrenes ressourcer og bidrag som en fast del af at udvikle den pædagogiske praksis. Sammenlignet med de kvantitative analyser er dette som sagt en effekt, der ikke kan måles. Vi kan derfor konkludere, at lederne oplever, at institutionerne er i gang med en udvikling på disse områder. Denne udvikling kunne også dokumenteres gennem konkrete eksempler på ændret praksis i forhold til tilrettelæggelse og opfattelse af forældresamarbejde. Der ses gennemgående en mere udviklingsorienteret og innovativ tilgang til forældresamarbejde. 
Der er i institutionerne arbejdet med at gøre forventninger og krav til forældrene tydelige og konkrete - og samtidig differentierede, så forældres forskellige ressourcer kan komme i spil. Det er fortsat en udfordring i dagtilbuddene reelt at praktisere åbenhed og at fastholde et ressourceperspektiv i personalegruppen i forhold til forældrene. Det formuleres som en udfordring at gøre det pædagogiske arbejde nærværende og tydeligt for forældrene. Endvidere er det en udfordring at arbejde med inklusion i forældregruppen.

Ved den individuelle interviewrunde (2011) blev der identificeret både interne og eksterne udfordringer i forhold til forældreinddragelse. Vi ser i datamaterialet et billede af, at opmærksomheden i 2013 har flyttet sig til primært de interne udfordringer. Det vil sige, at der i institutionerne er en $\emptyset$ get opmærksomhed på, at arbejdet med forældreinddragelse kræver ændringer i egen praksis, i institutionens måde at organisere forældresamarbejde på og i forhold til medarbejdernes forståelse af og tilgang til forældre. Det må antages at hænge sammen med en større grad af fokus på forældrenes forskelligartede ressourcer og forskellige muligheder for at bidrage.

\section{Interventionen oplevet af forældrene}

De kvalitative analyser af forældreinterview viser, at forældre lægger vægt på, at 1) der er en tydelig struktur og planlægning i institutionen, og 2) at de kan se de pædagogiske begrundelser for, hvorfor hverdagen er tilrettelagt, som den er, 3) at de kan få øje på pædagogernes engagement og vilje til at yde en indsats i arbejdet med børnene, samt 4) at der er 'god stemning', forstået som at forældrene kan føle sig velkomne og få kontakter til og dialog med de andre forældre.

Analysen viser, at projekter, hvor den pædagogiske praksis bliver konkret og nærværende for forældrene, betyder meget i relation til ovenstående. Ligesom det har stor betydning, om forældrearrangementer er tilrettelagt på en sådan måde, at det konkret underst $\varnothing$ tter forældrenes samtaler indbyrdes og mulighed for at komme i snak.

Analysen peger videre på, at de eksperimenter, som institutionerne har gennemført i forbindelse med deltagelse i VIDA-programmet, har bidraget til udvikling set fra forældrenes perspektiv. De konkrete pædagogiske aktiviteter har givet forældrene en bedre oplevelse af, hvad deres barn bruger sin tid på i institutionen - og det betyder bedre mulighed for dialog med deres barn om, hvad der foregår i institutionen. På den måde får forældrene en oplevelse af at kunne bidrage relevant til deres barns udvikling og trivsel. 
Samlet set viser interviewene, at forældrene lægger vægt på, at der kan skabes en ligeværdig dialog og gives st $\varnothing$ tte til vanskelige situationer og samspil. På den måde kan dagtilbuddet blive en ressource for familien. Dette kan lade sig gøre, når der er tillid mellem forældre og institution, og dialoger gennemf $\varnothing$ res i et anerkendende miljø, der lægger vægt på forskelle som ressource.

Opsummerende viser analysen, at der på baggrund af deltagelse i VIDA arbejdes mere systematisk med at inddrage forældrene og indtænke forældrenes ressourcer som en fast del af at udvikle den pædagogiske praksis i de deltagende dagtilbud (VIDA-Basis +). Der er i institutionerne arbejdet med at gøre forventninger og krav til forældrene tydelige og konkrete - og samtidig differentierede, så forældres forskellige ressourcer kan komme i spil. Det er gennemgående, at dagtilbuddene har arbejdet med at revurdere og gentænke deres forældrearrangementer både $i$ indhold og form. Der arbejdes med mere dynamiske arrangementer, med aktiviteter, dialog og interaktion, som er struktureret og underst $\varnothing$ ttet af personalet. Endvidere tænkes der i at være mere direkte ops $\emptyset$ gende og inviterende over for forældre, som ikke plejer at deltage.

Vi ser på den måde gennemgående en mere udviklingsorienteret og innovativ tilgang til forældresamarbejdet. I flere institutioner fremhæves det, at institutionens arbejde med forældreinddragelse har haft en betydning i forældregruppen på den måde, at forældrene er mere accepterende og inkluderende over for hinanden. Der er endvidere også flere eksempler på, at forældre kan bruge personalet som sparringspartnere i forhold til de vanskeligheder, de oplever i relation til deres barn.

Der er i institutionerne en $\emptyset$ get opmærksomhed på, at arbejdet med forældreinddragelse kræver ændringer i egen praksis, i institutionens måde at organisere forældresamarbejde på og i forhold til medarbejdernes forståelse af og tilgang til forældrene. Det må antages at hænge sammen med en st $\varnothing$ rre grad af fokus på forældrenes forskelligartede ressourcer og forskellige muligheder for at bidrage. Casestudiet belyser ved udvalgte forældreinterview også et forældreperspektiv. Forældrene lægger vægt på, at der er en tydelig struktur og planlægning i institutionen, og at de kan 'få фje på pædagogikken' eller de pædagogiske begrundelser for, hvorfor hverdagen er tilrettelagt, som den er. Derfor betyder aktiviteter, hvor den pædagogiske praksis bliver konkret og nærværende for forældrene, meget - der hvor de kan få en fornemmelse af, hvad deres barn bruger sin tid på i institutionen og kan få konkrete indspil til at have dialoger med barnet om dette. 
Når børnene er engageret i sådanne aktiviteter eller projekter, 'smitter' det af hos forældrene og skaber et fælles bindeled til institutionen. Endvidere lægger forældrene vægt på, at der kan skabes en ligeværdig dialog og gives st $\varnothing$ tte til vanskelige situationer og samspil. På den måde kan dagtilbuddet blive en ressource for familien og forældrenes samspil med barnet. Dette kan lade sig gøre, når der er tillid mellem forældre og institution. Det har ligeledes betydning, at forældrene får en oplevelse af at kunne bidrage relevant til deres barns udvikling og trivsel. Et gennemgående tema er endvidere 'stemningen' i institutionen, at forældrene kan 'føle sig hjemme' og få en kontakt til de andre forældre. Her har det stor betydning, om forældrearrangementer er tilrettelagt på en sådan måde, at det konkret underst $\varnothing$ tter forældrenes samtaler indbyrdes og mulighed for at komme i snak.

Unders $\varnothing$ gelsen af dagtilbuddenes arbejde med forældreinvolvering viser samlet set, at der ikke er sket signifikante ændringer i fordelingen eller organiseringen af forældrearrangementer som helhed, men derimod signifikante ændringer i prioriteringen af forældresamarbejdet og -involvering. Denne prioritering går især i retning af en højere grad af reflektorisk dialog, forældre-til-forældre-kontakt og forældrenes deltagelse i institutionens praktiske daglige liv og arrangementer. Der er endvidere sket en signifikant stigning i deltagelse i kurser i forældresamarbejde, mens der ikke er signifikante forskelle på organisering og prioritering af forældresamarbejde i VIDA-Basis-/VIDA-Basis +-dagtilbuddene sammenholdt med kontrolgruppen på de berørte områder.

Inden for områderne debat og fælles refleksion, aktiv forældreinddragelse $i$ institutionens dagligdag og/eller særlige arrangementer samt kontakt mellem forældre indbyrdes kan der således på baggrund af analysen findes nogle særlige udviklingsmuligheder for de danske dagtilbud. Den videre forskning vil gennem udvalgte caseinstitutioner følge, hvordan udviklingen af forældresamarbejde og -involvering realiseres i praksis, samt hvilke udfordringer og dilemmaer der opstår i den forbindelse.

\subsection{SAMMENFATNING}

Første del af analysen af casestudier, der er præsenteret i dette kapitel, viste opsummerende, at der er fundet markante, store virkninger af VIDA i positiv retning på især tre punkter vedrørende organisatorisk læring: 
- Mere fokus på at arbejde med viden og på det at arbejde vidensbaseret, målrettet og systematisk med udsatte børn gennem forandringer af arbejdspladskulturen

- Endrede ledelsesformer, lederroller og organisatorisk læringskapacitet, herunder en $\emptyset$ get oplevelse blandt medarbejderne af at møde opmuntring, støtte og positiv respons på udvikling af nye idéer og handlemåder

- $\quad$ gede forventninger til VIDA-programmets effekter på kort og langt sigt og $\varnothing$ get motivation for at arbejde med VIDA for tre ud af fire kommuner.

Når det er sagt, må vi også erkende, at det stadig er en udfordring at arbejde med fornyelse på baggrund af VIDA-programmet på følgende to områder: Ressourcesynet er stadig en udfordring. Dette at arbejde væk fra 'fejlfinding' og hen imod at se på ressourcer hos børn, forældre og personale er slået igennem de fleste steder, men det er stadig en udfordring at få alle medarbejdere med, som lederne udtrykker det i interview. Så selv om lederne fremhæver, at der nu arbejdes mere teoribaseret som følge af VIDA-programmets perspektiver, så er medarbejdergruppen forskelligartet, og denne gruppes forskelligheder er det en væsentlig ledelsesopgave at arbejde med - især i relation til VIDA-programmets mål. Ledelsen af organisatorisk læring har som nævnt udviklet sig på afgørende vis fra 2011 til 2013. Der, hvor vi stadig ser udfordringer, er i forhold til medarbejdernes oplevelse af medinddragelse. Dette punkt så vi også i en tidligere analyse (midtvejs), og der er således stadig behov for at udvikle lige netop dette aspekt, så lederen differentierer mellem medarbejdere, men samtidig sikrer sig, at medarbejderne reelt oplever at være inddraget.

Konklusionen på anden del af casestudieanalysen vedrørende implementering af forandringsprocesser som følge af VIDA-Basis +-forældreprogrammet er, at der er sket en række forandringer på dette område. Vi ser overordnet, at der gennemgående arbejdes med en mere udviklingsorienteret og innovativ tilgang til forældresamarbejde end i udgangspunktet. I flere institutioner fremhæves det, at institutionens arbejde med forældreinddragelse har haft en betydning i forældregruppen, på den måde at forældrene er mere accepterende og inkluderende over for hinanden. Der er endvidere flere eksempler på, at forældre kan bruge personalet som sparringspartnere i forhold til de vanskeligheder, de oplever i relation til deres barn. 
De udfordringer, der stadig foreligger i forhold til VIDA-Basis +-programmet er:

- Bevægelsen fra et fejl-/mangelsyn til et ressourcesyn i forhold til børn og forældre er en udfordring. Personalet er meget forskellige steder, og stuerne griber det meget forskelligt an.

- Der er behov for andre måder at arbejde sammen på i personalegruppen, da udvikling af forældreinddragelse også handler om at arbejde med egen faglighed og samarbejde. I den sammenhæng er det en udfordring med professionalitet/faglighed omkring det at skabe ligeværdig dialog og at kunne håndtere forskelle som ressourcer og se forældre som bidragende.

- Variation i kommunikation og formidling til forældre, overskridelse af barrierer i forhold til direkte kontakt samt fastholdelse af et ressource- og anerkendelsesperspektiv i forbindelse med rådgivning og vejledning. 


\section{KAPITEL 4}

\section{REFLEKSION OVER FORSKNINGS- PROGRAMMETS RESULTATER}

Et af målene med VIDA-forskningsprogrammet er at skabe højkvalitetsdagtilbud gennem professionel udvikling og et kvalificeringsprogram, der har som formål at l $\varnothing \mathrm{fte} b \varnothing \mathrm{rns}$ kompetenceudvikling gennem professionelles mere teoretisk funderede, målrettede og systematiske arbejde med fornyelse af pædagogisk praksis med fokus på organisatorisk læring (VIDA-Basis). I forskningsprogrammet undersøger vi derfor ligeledes, om denne kompetenceudvikling reelt set slår igennem målt på børns udbytte. Et andet af målene med VIDA-forskningsprogrammet er at udvikle og unders $\varnothing$ ge, om uddannelse af professionelle til at implementere et fornyet forældreinvolverende samarbejde (VIDA-Basis +) vil kunne højne den pædagogiske kvalitet - og om dette også sætter sig igennem målt på børns udbytte.

Vi finder, at VIDA-modelprogrammerne har gjort en stor forskel, og især har der vist sig store virkninger af den professionelle kvalificering rettet mod at forandre praksis gennem organisatorisk læring. Vanskeligere har det vist sig at være at implementere et nyt involverende forældreprogram. VIDA-Basis +-forældreprogrammet har haft betydning i de deltagende institutioner, bl.a. i forhold til tilrettelægningen og prioriteringen af forældresamarbejdet, men som vist i sammenfatningen ovenfor er der stadig mange udfordringer på dette område. 


\subsection{SOCIAL ARV SOM SOCIAL OG KULTUREL ULIGHED - HVORDAN GØR VIDA EN FORSKEL?}

Vi finder som vist ovenfor, at interventionsprogrammet helt overordnet påvirker alle børns kompetencer, uanset social og kulturel baggrund, i positiv retning på op til flere dimensioner, når vi ser på de gennemsnitlige resultater. På to dimensioner af SDO har VIDA vist sig at have signifikant, positiv effekt. Det drejer sig om, at børns emotionelle problemer og deres adfærdsproblemer mindskes, hvilket må siges at være et vigtigt resultat af en forholdsvis kortvarig intervention (to år). De øvrige tre dimensioner er også forbedrede, hvilket vil sige, at hyperaktivitet er sjældnere og kammeratskabsproblemer mindre, ligesom børns prosociale adfærd er fremmet. Disse forbedringer er dog ikke signifikante. De sociale kompetencer forbedres således helt overordnet gennem VIDA-programmet for alle børn, og som vist i litteraturen er netop de sociale og emotionelle kompetencer af stor betydning for børns trivsel og læring på kort sigt, i dagliglivet i institutionen, hjemme i familien og på længere sigt ved indgangen til skolen, i skoleforl $\varnothing$ bet og videre frem. De socioemotionelle kompetencer udg $\varnothing \mathrm{r}$ en slags fundament for den $\emptyset$ vrige kompetenceudvikling og et udgangspunkt for barnets selvværds- og identitetsdannelse samt for dets ressourcer til at begå sig i sociale fællesskaber og til at navigere i livet.

På den ene side gør VIDA-programmet således en forskel for alle børn - og dermed også for socialt udsatte børn. På den anden side afspejler analyserne af de heterogene effekter på sin vis, at den sociale arv, hvor vi allerede i vores baselinemålinger fandt betydelige forskelle mellem børn fra forskellige sociale lag, hvad angår deres socioemotionelle og kognitive kompetencer, også viser sig efter VIDA-interventionen. Dvs., at selvom vi finder positive effekter overordnet set for alle børn og dermed også for de mest udsatte børn, så er det ikke sådan, at der er påvist bedre effekter for socialt udsatte børn end for andre børn. Med andre ord mindskes de sociale og kulturelle forskelle mellem grupperne ikke gennem deltagelse i VIDA.

Som svar på spørgsmålet om, hvordan VIDA gør en forskel, kan vi hævde, at VIDABasis-programmet gør en positiv forskel målt på børns udbytte, og som vist har det at gøre med, at programmet i størsteparten af institutionerne er implementeret efter hensigten. Dog ser vi i analysen af heterogene effekter, at den positive effekt ikke som håbet eller forventet er større for de mest udsatte grupper. Mht. effekten af VIDA-Basis +-programmet er svaret et andet, da effekterne her kun er få. Denne overordnede konklusion stemmer på sin vis godt overens med de fund, vi har gjort i casestudiet, at VIDA-Bais +-programmet har været vanskelig at im- 
plementere for institutionerne. Casestudiet peger på, at forældreinddragelsen, som er s $\emptyset$ gt udviklet i VIDA-Basis +-programmet, er noget nyt for institutionerne og derfor vanskeligt at implementere efter hensigten. Udsagn fra forældre vidner om et tilstedeværende engagement, men også om at dagtilbuddene ikke i tilstrækkeligt omfang 'når forældrene', der hvor deres behov er.

Sammenfattende viser effektanalyserne suppleret med casestudier, at VIDAprogrammet gør en forskel på nogle områder, og at der på andre områder er en række udfordringer til stede, som må analyseres yderligere for at nærme sig mere eksakte svar på de opstillede forskningsspørgsmål.

\subsection{FORUDS/ETNINGER FOR FORANDRINGER}

Gennem de casestudier, der sideløbende med effektanalyser er gennemf $\varnothing$ rt i VIDA-forskningsprogrammet, opnår vi indsigt i, hvilke forudsætninger der er til stede i dagtilbuddene for at skabe forandringer af de pædagogiske praksisser. Vi har endvidere fået indblik i, hvilke forandringer der er realiseret som følge af deltagelse i VIDA-programmet. Vi har set, at en signifikant st $\varnothing$ rre andel af institutioner nu i højere grad arbejder vidensbaseret, målrettet og systematisk. Vi har på den baggrund data, som gør det muligt at unders $\varnothing$ ge nærmere, hvilke forudsætninger der skal til for at opnå effekter, og vi kan fx gå videre og unders $\varnothing$ ge betydningen af medarbejderprofiler, lederprofil, personaleudskiftning, normeringer og børnesammensætning i den forbindelse.

Det er også værd at gøre sig nogle overvejelser over betydningen af kommunernes satsning på at deltage i VIDA-projektet, fx indikeret ved de ressourcer, de har tillagt projektet i form af konsulentbistand, support, coaching og evt. frik $\varnothing b$ af medarbejdere og vikardækning. Her har forudsætningerne været forskellige i de fire deltagende kommuner, og sådanne forskelle vil kunne bringes ind i efterfølgende analyser.

Endelig er det værd at dvæle ved betydningen af andre projekter, som parallelt med afprøvningen af VIDA-projektet var sat i gang i tre ud af fire kommuner.

De deltagende kommuner har således gennemf $\varnothing$ rt andre interventioner samtidig med VIDA, og i en af kommunerne blev der specifikt gennemf $\varnothing$ rt et 'Inklusionsprojekt' i 2011 for alle institutioner i kommunen. Dette bet $\varnothing d$, at både deltagende VIDA-institutioner og kontrolinstitutioner fra den pågældende kommune modtog denne indsats sideløbende med VIDA. En anden kommune implementerede 
- også sideløbende med VIDA - et såkaldt 'Visionsprojekt' for alle institutioner. Det forventedes ikke at give forskelle mellem VIDA- og kontrolinstitutioner, men projektet kunne potentielt set føre til (nedadgående) bias i effekterne af VIDA. I en tredje kommune startede et 'Inklusionsprojekt' i 2013 med at tilbyde efteruddannelse til pædagogerne i kommunen. Det forventedes ikke, at dette projekt ville kunne påvirke resultaterne af VIDA, da projektet startede næsten samtidig med, at den sidste dataindsamling fandt sted. I den fjerde kommune har der ikke fundet andre interventioner sted end VIDA i projektperioden.

En anden bekymring kunne dreje sig om udskiftning blandt det pædagogiske personale. Udskiftningen blandt pædagoger er generelt høj i Danmark på grund af fleksible ansættelsesforhold.. Udskiftningen i dagtilbud er imidlertid højest blandt de uuddannede, pædagogmedhjælperne, og da denne gruppe ikke er deltagere i de tilbudte uddannelses- og træningsprogrammer i VIDA, skulle dette ikke give de store problemer for designet.

Også en række faktorer, der knytter sig til kompetencemålingerne på de deltagende $b \emptyset r n$, kan potentielt set påvirke effekterne af VIDA. Vi ved ikke, hvilke pædagoger der har udfyldt spørgeskemaet for et bestemt barn, så vi kan ikke kontrollere for pædagogeffekter (fixed effects). Dvs., at vi ikke kan tage højde for, om nogle pædagoger bruger SDQ-skalaen eller de andre anvendte skalaer mere eller mindre generøst end andre. Men der er imidlertid ikke nogen grund til at tro dette, da det ikke så ud til at være et problem i det tidligere gennemf $\varnothing$ rte forskningsstudie HPA-projektet. Nogle af de børn, som deltog i VIDA-baselinedataindsamlingen, forlod institutionen $\mathrm{f} \varnothing \mathrm{r}$ den sidste dataindsamling (i marts 2013). Når et barn slutter i institutionen, er det typiske mønster, at et nyt barn kommer ind i institutionen, så der er altid en strøm af børn, der går ind og ud af daginstitutionerne. De fleste børn starter i skole i august det år, de fylder seks, men i nogle kommuner er børnene indskrevet i skolefritidsordninger allerede fra 1. maj det år, de starter i skolen. Dette er de normale skolefritidsordninger, bortset fra at disse små børn bliver passet der fuldtids. For at kontrollere for sådanne kommunale forskelle i børnepasningsordninger har vi tilføjet 'fixed effects' til vores estimater. Dette vil også gælde for de nævnte sideløbende inklusions- og visionsprojekter, som er implementeret i tre af kommunerne.

Opsummerende vidner sådanne forhold om, at der er en række forskellige faktorer på færde i en kompleks og lokalt forankret institutionshverdag, som kan gå hen og påvirke effekter af en så stor satsning, som VIDA-programmet har været. 


\subsection{EFFEKTER OVER TID, VILKÅR OG RESSOURCER}

Vi har med data fra VIDA mulighed for videre frem at unders $\varnothing$ ge, om der kan opnås langtidseffekter, også for de mest udsatte børn. Hypotesen om, at deltagelse

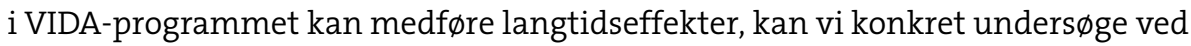
at følge gruppen, der har deltaget i VIDA, videre frem gennem livsforl $\varnothing$ bet, idet vi har børnenes CPR-numre.

Det vil således være af stor samfundsmæssig interesse at følge, om denne kvalitetsforbedring, der rent faktisk er sket i institutionerne som følge af VIDAprogrammerne, på længere sigt styrker børns trivsel og læring. Det er håbet, at en sådan professionel kvalificeringsproces kan være en forudsætning for, at vi som samfund gennem daginstitutioner måske ligefrem kan bidrage til at reducere de sociale og kulturelle forskelle, som social arv-forskningen peger på. Disse forskelle er om muligt endnu mere afg $\phi$ rende end $\varnothing$ konomiske forskelle i forhold til menneskers livschancer, og som følge deraf har uddannelsesinstitutioner en vigtig opgave fremover.

Vi kan desuden arbejde videre ud fra en hypotese om, som også Heckmann peger på, at indsatser skal starte endnu tidligere, dvs. i vuggestuen, og vare i længere tid og derved fortsætte ind i skolen, fx som et niårigt forløb med den samme målrettethed i indsatsen, som VIDA har påbegyndt. Her vil det være spændende at unders $\phi$ ge, om de påviste effekter viser sig at holde og måske ligefrem højnes senere - da vi netop ved, at den ballast, børn har fået med sig fra tidligste alder, kan have synergieffekt videre frem. 



\section{AFSLUTNING}

Formålet med VIDA-forskningsprogrammet har været at bidrage med ny viden om mulighederne, der ligger i en målrettet satsning på at styrke kvalitet i dagtilbud gennem professionel kvalificering. I forskningsprogrammet har vi både unders $\emptyset$ gt effekter af denne satsning målt på børns udbytte, non-kognitivt og kognitivt, og på de forandringer, der er sket i institutionerne som følge af deres deltagelse i interventionsprogrammet. Sådanne forandringer er unders $\varnothing$ gt ved at sætte fokus på, hvordan organisatorisk læring og innovation udvikler sig som følge af VIDA-programmet. Endvidere har vi også unders $\varnothing$ gt, hvordan nye former for forældreinddragelse udvikler sig som følge af VIDA-programmet.

Hovedindtrykket fra programmets overordnede effektmåling og de to delundersøgelser, som er gennemf $\varnothing$ rt som casestudier, er, at VIDA-interventionen overordnet set har positiv effekt både på børns gennemsnitlige sociale kompetenceudvikling og trivsel.

Det forhold, at der ikke som forventet er opnået effekt for så vidt angår børnenes kognitive læring og en særlig effekt ift. de mest udsatte børn kan have flere forklaringer. Én af dem kan være den forholdsvis korte indsatsperiode på 2 år. Flere f $\varnothing$ rende forskere understreger betydningen og relevansen af longitudinelle børnestudier og det at unders $\varnothing$ ge langtidseffekter.

Amerikansk forskning viser at børns livschancer grundlægges fra den tidligste barndom og at tidlig indsats er bedre end senere indsats. Det er endvidere påvist, at barnets trivsel, dvs. dets socio-emotionelle kompetencer, er lige så vigtige 
som kognitive kompetencer i forhold til at forstå, hvad der skaber grundlaget for børns livschancer og videre udvikling. Udvikling af kompetencer, der gør barnet skoleparat og medvirker til barnets trivsel og identitetsdannelse, inkluderer både barnets sproglige kompetencer, dets kognitive færdigheder og dets evner til at indgå i sociale relationer med andre menneske. Styrkelse af børns socio-emotionelle udvikling og trivsel må antages at give positive effekter for barnets videre skolegang, uddannelse og videre frem i livet.

Nyere dansk forskning baseret på registerdata vidner endvidere om, at der kan opnås langtidseffekter af høj-kvalitets dagtilbud, således at. børnehaver med gode normeringer og $h \phi j$ andel af uddannet personale højner børns karakterer i 9. klasse. Her fandt man ikke effekter på de mest udsatte børn. Nyeste studie viser, at højkvalitets vuggestuer, dvs. dagtilbud med $h \varnothing j$ andel af uddannede, $h \varnothing j-$ ner karakterer for børn ved skolens afgangspr $\varnothing v e$. I dette studie ser vi en effekt også for udsatte børn, hvilket angiver, at den tidlige indsats allerede fra barnets vuggestuedeltagelse, giver positiv effekt.

Baseret på resultater fra disse internationale og danske longitudinelle studier forventes VIDA-modelprogrammet også at kunne vise langtidseffekter. To anbefalinger træder frem af resultaterne

- $\quad$ For det f $\varnothing$ rste at f $\varnothing$ lge b $\varnothing$ rnene over tid - dvs. unders $\varnothing$ ge om VIDA-modelprogrammet opnår langtidseffekter målt på børnenes karaktergennemsnit ved 9. klasse.

- $\quad$ For det andet at sætte ind med VIDA i danske dagtilbud mere generelt og supplere børnehaveindsatsen med en tilsvarende indsats i vuggestuen. 


\section{REFERENCER}

Jensen, B. (red.) (2011). Vidensbaseret indsats over for udsatte børn i dagtilbud modelprogram. VIDA-statusrapport 1. Design og metode. I: VIDA-forskningsserien, 2011:01, IUP, Aarhus Universitet.

Jensen, B. (red.) Vidensbaseret indsats over for udsatte børn i dagtilbud - modelprogram. VIDA-statusrapport 2. Baseline. I: VIDA-forskningsserien, 2011:03, IUP, Aarhus Universitet.

Jensen, B. (red.) Vidensbaseret indsats over for udsatte børn i dagtilbud - modelprogram. VIDA-statusrapport 3. Midtvejsanalyser. I: VIDA-forskningsserien, 2012:01, IUP, Aarhus Universitet.

Jensen, B. (red.) Vidensbaseret indsats over for udsatte børn i dagtilbud - modelprogram. VIDA-statusrapport 4. Udviklingstendenser. I: VIDA-forskningsserien, 2012:02, IUP, Aarhus Universitet.

Larsen, M.S., Bang-Olsen, A., Berliner, P., Bjørnoy Sommersel, H., Grosen Pedersen, A., Holm, A., Jensen, B., Müller Kristensen, R., Ploug, N., \& Neriman Tiftikci (2011). Programmer for 0-6 årige med forældreinvolvering i dagtilbud. En forskningskortlægning. I: VIDA-forskningsserien, 11:02. http://edu.au.dk/ forskning/projekter/vida/ og Frederikshavn: Dafolo.

Jensen, B., Jensen, P. \& Würtz Rasmussen (2013). Vidensbaseret indsats over for udsatte børn i dagtilbud - modelprogram. VIDA-forskningsrapport 1. Effekter af VIDA. I: VIDA-forskningsserien 2013:04. København: Institut for Uddannelse og Pædagogik, Aarhus Universitet. 
Jensen, B. \& Brandi,U. (2013). Vidensbaseret indsats over for udsatte børn i dagtilbud-modelprogram. VIDA-forskningsrapport 2. Organisatorisk læring. I: VIDA-forskningsserien 2013:05. København: Institut for Uddannelse og Pædagogik, Aarhus Universitet.

Kousholt, D. \& Berliner, P. (2013). Vidensbaseret indsats over for udsatte børn $i$ dagtilbud-modelprogram. VIDA-forskningsrapport 3. Forældreinddragelse. I:VIDA-forskningsserien 2013:06. København: Institut for Uddannelse og Pædagogik, Aarhus Universitet

Jensen, B. \& Haahr-Pedersen, J. (2013). Vidensbaseret indsats over for udsatte børn i dagtilbud-modelprogram. VIDA-modelrapport 3. VIDA I praksis. I: VIDA-serien 2013:03. København: Institut for Uddannelse og Pædagogik, Aarhus Universitet.

Se en samlet oversigt over VIDA-publikationer på projektets hjemmeside http:// edu.au.dk/forskning/projekter/vida/. 


\section{VIDA}

Vidensbaseret indsats over for udsatte børn i dagtilbud - modelprogram. Forskningsrapport 4. Forandring og effekt.

VIDA-forskningsrapport 4 sammenfatter resultaterne af case-og effektstudier, der er gennemført i VIDA-projektet 2011-2013.

Forskningsrapporten præsenterer den tilgang til pædagogisk fornyelse, som er udviklet og implementeret i VIDA-modelprogrammet. Desuden præsenteres de samlede resultater af studiet af effekter målt på børns udbytte og casestudier af organisatorisk læring og forældreinddragelse. Endelig diskuteres VIDA-projektets samlede fund og videre perspektiver.

Rapporten er udarbejdet som del af forskningsserien knyttet til projektet 'Vidensbaseret indsats over for udsatte børn i dagtilbud - modelprogram', som er bestilt og finansieret af Social, -Børne- og Integrationsministeriet og udviklet og evalueret af forskere ved Aarhus Universitet.

Målgruppen for rapporten er ministerier, kommuner, professionshøjskoler og andre, som $\emptyset$ nsker at arbejde videre ud fra VIDA-modelprogrammets principper, samt for $\neg$ skere og studerende, der $\varnothing$ nsker at få indblik i VIDA-programmets design, metoder og samlede analyser.

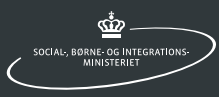

